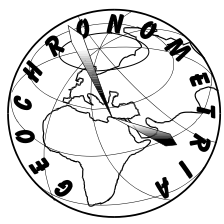

\title{
A CONTINUOUS STABLE ISOTOPE RECORD OF LAST INTERGLACIAL AGE FROM THE BULGARIAN CAVE ORLOVA CHUKA
}

\author{
JACEK PAWLAK ${ }^{1}$, MARCIN BLASZCZYK ${ }^{1}$, HELENA HERCMAN ${ }^{\mathbf{1}}$ and ŠÁRKA MATOUŠKOVÁ ${ }^{2}$ \\ ${ }^{I}$ Polish Academy of Sciences, Institute of Geological Sciences, Twarda 51/55, 00-818 Warsaw, Poland \\ ${ }^{2}$ The Czech Academy of Sciences, Institute of Geology, Rozvojova 269, CZ-165 00 Prague, Czech Republic
}

Received 8 November 2018

Accepted 11 March 2019

\begin{abstract}
Recent research shows that the last interglacial climate was more unstable in comparison to Holocene. Lack of suitable dating techniques and precisely defined absolute age benchmarks is one from main problems for present LIG studies. Therefore many of LIG chronologies base on indirect dating techniques like record alignment strategies. In this context, speleothems are valuable paleoclimate archives because of their capability to be dated by U-series method. In Europe LIG speleothem records are known mostly from western and central part of the continent. In this paper we present a 1,650 mm long stalagmite (ocz-6) from Bulgarian Cave Orlova Chuka. The ocz-6 stalagmite records the period of time ca. 129-112 ka. Ocz-6 stalagmite was analyzed in terms of stable isotopic composition of calcite and trace elements content. All analyzed geochemical proxies point to dynamic changes in the environment during the Last Interglacial time. At the time of interglacial development (129-126.5 ka), ocz-6 records shows systematic change in proportion of moisture delivered from Atlantic source and other sources. The beginning of last interglacial optimum is connected with a rapid change to more humid and warm conditions. During interglacial demise local climate become more dependent from regional settings.
\end{abstract}

Keywords: LIG, paleoclimate, speleothem, stable isotopes, trace elements.

\section{INTRODUCTION}

During the Pleistocene period, the Earth's climate has been dominated by ice age cyclicity, long cold periods (glacials) have been interrupted by shorter and warmer intervals, known as interglacials. The duration of the last interglacial (LIG) has conventionally been set at 129-116 ka based on sea level variations and marine records (Martinson et al., 1987; Dutton and Lambeck, 2012; Masson-Delmotte et al., 2013; Pedersen et al., 2017). In marine sediments, the LIG is defined as Marine Isotope Stage (MIS) 5e (Shackleton, 1969). The LIG in

Corresponding author: J. Pawlak

e-mail: dzeq@twarda.pan.pl continental Europe was defined as the Eemian; however, the Eemian does not cover the MIS 5e period (Otvos, 2015). The Eemian should be defined as the MIS 5e optimum (Govin et al., 2015). In comparison to the Holocene, the LIG climate was unstable. Several short events, connected with changes in moisture are observed in $\mathrm{Eu}-$ ropean records and Atlantic cores (Oppo et al. 2006; Couchoud et al., 2009; Regattieri et al., 2014). Possible explanation for this instability is changes in the North Atlantic Meridional Overturning Circulation (AMOC) dynamics (Regattieri et al., 2014). The climatic mechanisms and sequence of LIG events are only partially known (Cheng et al., 2009; Masson-Delmotte et al., 2010; Landais et al., 2013). For many archives like: ice cores, marine and lake cores, the main difficulty is reliable dating; those archives may not meet the specific requirements of radiometric dating techniques, also it may 
be difficult to find benchmarks with precise age, like tephra layers or magnetic excursions. Therefore, many LIG chronologies are based on indirect approaches, such as record alignment strategies (Govin et al., 2015). Speleothems are valuable archives because of their capability to be dated by the U-series method (Fairchild and Baker, 2012). In Europe, LIG speleothem records are mostly known from the western and central regions of the continent (Linge et al., 2001; Holzkamper et al., 2004; Drysdale et al., 2005, 2007, 2009; Munoz-Garcia et al., 2007; Meyer et al., 2008; Couchoud et al., 2009; Boch et al., 2011; Genty et al., 2013; Regattieri et al., 2014; Moseley et al., 2015; Vansteenberge et al., 2016; Demeny et al., 2017). Additionally low resolution speleothem isotopic $\left(\delta^{18} \mathrm{O}, \delta^{13} \mathrm{C}\right)$ records from Romania were reported by (Lauritzen and Onac 1999). In this study, we present speleothem isotopic $\left(\delta^{18} \mathrm{O}, \delta^{13} \mathrm{C}\right)$ and trace element records from the Bulgarian Orlova Chuka Cave. This is the first high-resolution isotopic record from LIG speleothems obtained in the region of southeastern Europe. This region is especially interesting for LIG climate studies because of the possible influences of Atlantic circulation, the Mediterranean Sea and Levant region.

\section{CAVE SETTINGS AND MATERIAL}

Orlova Chuka is one of the best-known caves in Bulgaria. This cave is located in Ruse Province in the northeastern part of the country (Fig. 1A). The present climate of the Ruse region is continental, with warm summers $\left(+22.4^{\circ} \mathrm{C}\right.$ average temperature for July) and relatively cold winters $\left(-1.3^{\circ} \mathrm{C}\right.$ average temperature for January). The yearly average temperature is $+11.2^{\circ} \mathrm{C}$. The precipitation is relative stable during the year. The difference between the driest month (March) and the wettest (June) is $42 \mathrm{~mm}$. The yearly average precipitation is $585 \mathrm{~mm}$. Currently, the Atlantic and Mediterranean circulation exert the main influences on the climate in this region (Malcheva et al., 2015; Nojarow, 2018). Present winter precipitation depends on Meditererranean cyclones, when they pass on more northwest the winters are softer with subnormal precipitation, when those cyclones passes on more southern ways the winters are colder with greater precipitation (Malcheva et al., 2015). The summer conditions depend from the proportion between northward and eastward transport of moisture. Domination of northward direction leads to warmer and dryer summers (Nojarow, 2018).

The cave entrance is situated on the northeastern slope of the Cherni Lom river valley, which is $150 \mathrm{~m}$ above sea level (Evlogiev et al., 1997). The cave system is situated just below the old river terrace $c a$. $60 \mathrm{~m}$ above the present level of the Cherny Lom River. This terrace corresponds to erosional surface formed during the Pliocene $c a$. $2.59 \mathrm{Ma}$ on the southern margin of the Dacian Basin (Evlogiev, 2000). Orlova Chuka is a network maze cave comprising sub-horizontal passages with the total length of 13,437 m (Fig. 1B). The morphology of the cave passages suggests their phreatic origin. Presently, the cave passages are filled with cave sediments that reach approximately two-thirds of their height. Flowstone hanging $c a$. $1.5 \mathrm{~m}$ above the present sediment surface suggested that in the past, almost the entire cave passage was filled with cave sediments. The cave sediments in Orlova Chuka were investigated in a pit located $20 \mathrm{~m}$ from the cave entrance (Evlogiev et al., 1997). The sedimentary profile contains several types of rocks: weathering detritus, aeolian silts, thermoclastic fragments and speleothems (Fig. 1C). The Brunhes/Matuyama (0.78 Ma) boundary is

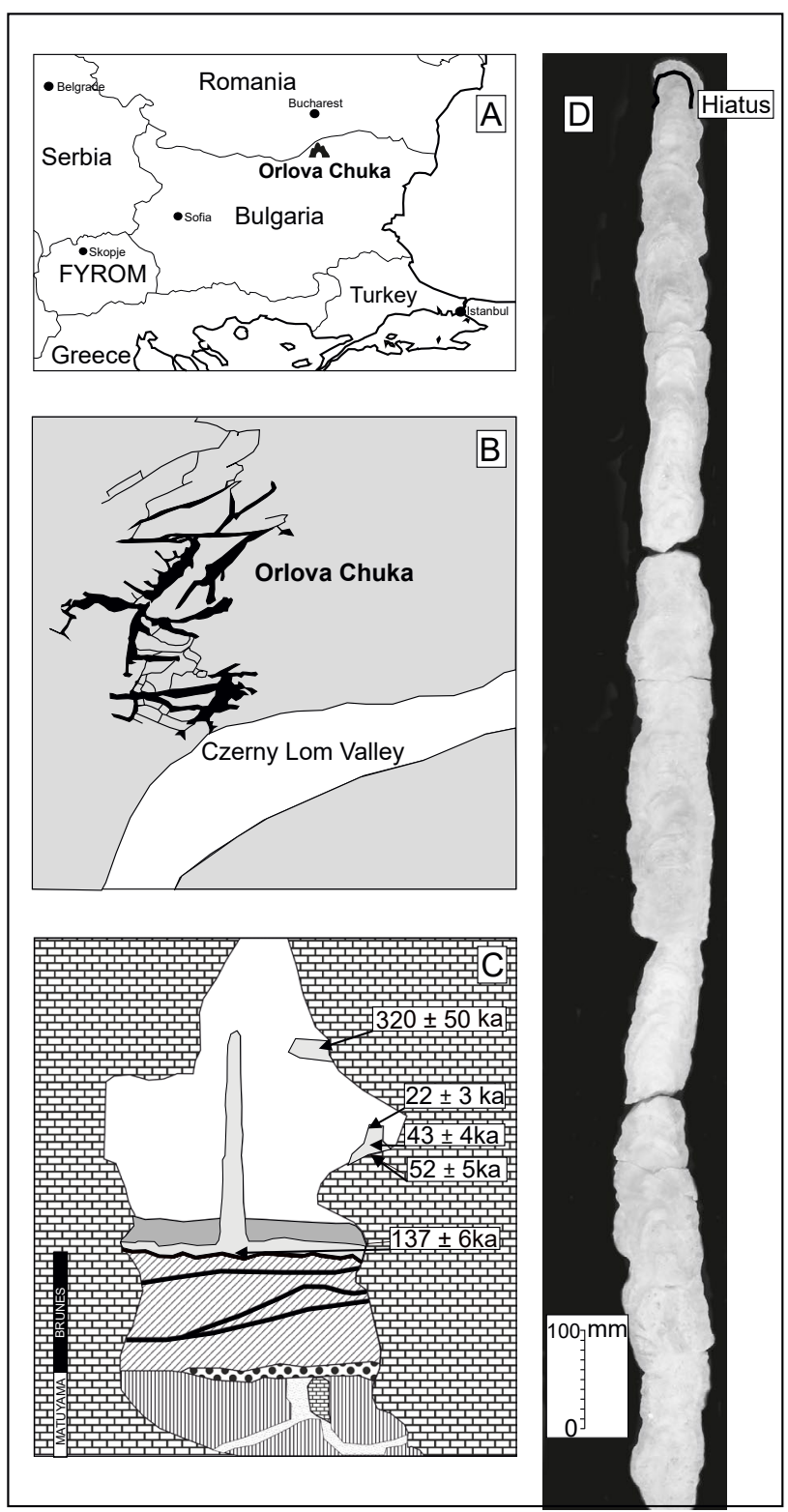

Fig. 1. Sample locations: A - Orlova Chuka Cave location; B - Sketch of the Orlova Chuka Cave basing on material from official cave web page www.dvemogili.bg; $C$ - Cross section of the Orlova Tchuka Cave sediments; $D$ - Ocz-6 sample. 
located at a depth of $1.20 \mathrm{~m}$ in this sedimentary sequence (Evlogiev et al., 1997). The clastic profile is covered by the flowstone layer (Fig. 1C). The archival U-series alpha spectrometry dating of the flowstone base yielded an age of $137 \pm 6 \mathrm{ka}$ (Fig. 1C). The studied stalagmite (ocz-6) grows up from this flowstone layer. The flowstone layer is covered by aeolic sediments whose age is most likely Vistulian (Fig. 1C). Ocz-6 is a ca. 1,650-mm-long columnar stalagmite with a diameter of $c a .80 \mathrm{~mm}$ (Fig. 1D). It mainly consists of a $c a$. 1,630-mm-long section of continuous growth and one narrow upper layer that is approximately $20 \mathrm{~mm}$ high (Fig. 1D). Both layers are separated by a speleothem growth break period (Fig. 1D hiatus). The ocz-6 stalagmite comprises several types of calcite that exhibit different colors, detrital material admixtures, porosities and other calcite crystal features. Most of the stalagmite comprises compact, light yellow and delicately laminated calcite. Only the section from 180 to $610 \mathrm{~mm}$ above the base has higher porosity.

\section{METHODS}

\section{Petrography}

Eight thin sections were collected along the growth axis of ocz-6 stalagmite from places with different macroscopic characteristic of the calcite. The main goal of microscopic observation was to study the typical microstructures of the stalagmite, such as fabric types, microscale discontinuities, porosities and inclusions. These microscopic observations were obtained using the Nikon Eclipse LV100POL microscope from the Institute of Geological Sciences at the Polish Academy of Sciences (Warsaw, Poland). The analyses and descriptions of the speleothem fabrics were based on the methodology proposed by Turgeon and Lundberg (2001) and Frisia (2015). As a result of the calcite fabric analysis, it was possible to briefly characterize the conditions that occurred during stalagmite precipitation (Turgeon and Lundberg, 2001; Frisia, 2015).

\section{U-series dating and age-depth model construction}

A series of $0.1-0.5 \mathrm{~g}$ calcite samples were obtained by drilling along the growing layers. The average thickness of each drilled sample was $2 \pm 0.2 \mathrm{~mm}$. The chemical procedure of $U$ and $T h$ separation was performed at the U-series Laboratory of the Institute of Geological Sciences, Polish Academy of Sciences (Warsaw, Poland). First the samples were treated by high temperature for decomposition of the organic matter. The isotopic spike ${ }^{233} \mathrm{U}$, ${ }^{236} \mathrm{U},{ }^{229} \mathrm{Th}$ ) was added to the samples before the chemical procedure. Samples were dissolved by nitric acid during chemical procedure. Finally uranium and thorium were separated from carbonate matrix by the chromatographic method (TRU Resin). Internal standards and blank samples were treated by the same procedure as all studied samples. The measurement of $\mathrm{U}$ and $\mathrm{Th}$ isotopic compo- sitions of all samples and standards was performed at the Institute of Geology of the Czech Academy of Sciences (Prague, Czech Republic), by a double-focusing sectorfield ICP mass analyzer (Element 2, Thermo Finnigan MAT). The instrument was set on a low mass resolution $(\mathrm{m} / \Delta \mathrm{m} \geq 300)$.

Obtained results first were corrected for background counts and chemical blanks and finally are reported as the activity ratios. U-series ages were calculated based on measured ${ }^{230} \mathrm{Th} /{ }^{234} \mathrm{U}$ and ${ }^{234} \mathrm{U} /{ }^{238} \mathrm{U}$ activity ratios using the newest decay constants (in $\mathrm{yr}^{-1}$ ): $\lambda_{238}=(1.55125 \pm 0.0017) \cdot 10^{-10}$ (Jaffey et al., 1971), $\lambda_{234}=(2.826 \pm 0.0056) \cdot 10^{-6} \quad($ Cheng et al., 2013), $\lambda_{232}=(4.95 \pm 0.035) \cdot 10^{-11} \quad$ (Holden, 1990), and $\lambda_{230}=(9.1577 \pm 0.028) \cdot 10^{-6}$ (Cheng et al., 2013$)$. The age errors were calculated with taking into account all uncertainties using error propagation rules. Isotope of ${ }^{232} \mathrm{Th}$ is an indicator of potential contamination of the sample by thorium and uranium from non-calcite source. Previously, for $\alpha$ spectrometry data, value of 20 for ${ }^{230} \mathrm{Th} /{ }^{232} \mathrm{Th}$ activity ratio was considered as a border value for clean samples. However higher detection ability of mass spectrometry moves this value up to 200-300 (Hellstrom, 2006). Samples with lower ${ }^{230} \mathrm{Th} /{ }^{232} \mathrm{Th}$ ratio should be corrected. Basically there are two groups of correction methods. First group of methods bases on arbitral assumption of initial ${ }^{230} \mathrm{Th} /{ }^{232} \mathrm{Th}$ ratio in contaminant $\left(\mathrm{B}_{0}\right)$. The second group of methods, like isochrones or method proposed by Hellstrom (2006), assumes that initial ${ }^{230} \mathrm{Th} /{ }^{232} \mathrm{Th}$ ratio can be calculated from the model. We decide to use modified algorithm proposed by Hellstrom (2006). Obtained ages were corrected with assumption of initial sample contamination by ${ }^{230} \mathrm{Th},{ }^{234} \mathrm{U},{ }^{238} \mathrm{U}$ isotopes. The algorithm was searching for possible the lowest initial contamination ratios $\left(\mathrm{B}_{0}, \mathrm{U}_{1}, \mathrm{U}_{2}\right)$ values which were able to correct series of ages in stratigraphic order. Based on the $\mathrm{U}$-series dating results, an age-depth model was created using the MOD-AGE algorithm (Hercman and Pawlak, 2012). The age and depth values are described as normal distributions, and the LOWESS technique was used to estimate age-depth relationships. The SPAN value defines how many data points are used to estimate the age value of every single point (see Cleveland, 1979). In general, higher values of SPAN produce smoother models. The chosen SPAN value for the LOESS model was 0.38 , which represented the highest value of SPAN which allowed the estimation of an age-depth model corresponding to all data points inside the $2 \sigma$ error band (Hercman and Pawlak, 2012).

\section{Stable isotopes}

The samples used for stable isotope analyses were drilled using a Dremel with a drill bit diameter of $0.5 \mathrm{~mm}$. All samples for isotopic profile were taken directly from axial part of stalagmite at approximately $2.0 \pm 0.2 \mathrm{~mm}$ increments from the stalagmite base at $0 \mathrm{~mm}$ to the discontinuity at $1,630 \mathrm{~mm}$, producing 
798 samples. Additionally, four profiles were sampled along the growing layers at different distances from the stalagmite base, i.e., profile I at $122 \pm 0.2 \mathrm{~mm}$; profile II at $834 \pm 0.2 \mathrm{~mm}$; profile III at $1,016 \pm 0.2 \mathrm{~mm}$; and profile IV at 1,528 $\pm 0.2 \mathrm{~mm}$ (supplementary Fig. S1). The isotope ratios of $\delta^{18} \mathrm{O}$ and $\delta^{13} \mathrm{C}$ were measured using a Thermo Kiel IV carbonate device connected to a Finnigan Delta Plus IRMS spectrometer in dual inlet mode at the Stable Isotope Laboratory of the Institute of Geological Sciences, Polish Academy of Sciences (Warsaw, Poland). $\mathrm{CO}_{2}$ was extracted from calcite using orthophosphoric acid (density: $1.94 \mathrm{~g} / \mathrm{dm}^{3}$ ) at $70^{\circ} \mathrm{C}$. The international standard NBS-19 was analyzed after every ten samples. The isotope ratios were reported as delta $(\delta)$ values and expressed relative to the VPDB standard. Oxygen and carbon analyses yielded measurement precisions of $0.1 \%$ and $0.05 \%$, respectively ( 1 standard deviation).

\section{Trace elements}

The trace element compositions were analyzed by LA-ICP-MS at the Institute of Geology of the Czech Academy of Sciences (Prague, Czech Republic) using an Analyte Excite Excimer Laser Ablation System with a wavelength of $193 \mathrm{~nm}$ and an Element 2 inductively coupled plasma mass spectrometer (Thermo Finnigan). Using a laser output of $50 \%$ with $10-\mathrm{Hz}$ pulses, we achieved a fluence of $2.44 \mathrm{~J} / \mathrm{cm}^{2}$. The width of each line was $50 \mu \mathrm{m}$, and the laser speed during each scan was $5 \mu \mathrm{m} / \mathrm{s}$. Additional details of the LA-ICP-MS analytical procedure were described by Eggins et al. (1997).

The analyses of near-surface trace elements, namely, $\mathrm{Mg}, \mathrm{Sr}, \mathrm{Zr}, \mathrm{Ba}, \mathrm{Na}, \mathrm{P}, \mathrm{Si}, \mathrm{Cr}, \mathrm{Mn}, \mathrm{Fe}, \mathrm{Al}, \mathrm{Cu}, \mathrm{Zn}, \mathrm{Ni}, \mathrm{U}$ and $\mathrm{Th}$, were performed at low and medium resolution. The laser ablation has been done continuously along the profile line with average sampling resolution of $3 \mu \mathrm{m}$ for medium resolution and $6 \mu \mathrm{m}$ for low resolution. The trace element content obtained from laser ablation analyses were normalized to $\mathrm{Ca}$ content. The profiles were measured along the longitudinal growth axes in six thin sections.

\section{RESULTS}

\section{Petrography}

The ocz-6 stalagmite comprises five different types of calcite hereafter designated as: A, B, C, D, and E types (Fig. 2). The main part of the ocz-6 stalagmite is dominated by alternating types A and B (Fig. 2). Type A is a compact light yellow calcite with very delicate laminations that are most likely related to changes in the sizes of crystals and changes in the amount of inclusions. A typical columnar compact fabric is dominant, and it exhibits narrow overlays of the columnar open fabric (Figs. 3A, 3B). Its porosity and level of detrital contamination are low. Type B has a milky white color without lamination.
It is characterized by a higher porosity than type A but does not exhibit detrital contamination. The observed fabrics are mainly alternating columnar open and columnar compact fabrics (Figs. 3C, 3D). Medium-grained calcite crystals are elongated perpendicular to the boundaries of layers. Type $\mathrm{C}$ is mostly located between 180 and $610 \mathrm{~mm}$ from the base marked on Fig. 2 as a porous zone. It is distinguished by its very high porosity, with pores up to several $\mathrm{mm}$ in size that are much larger than those in the other parts of the stalagmite; in these pores, the presence of opaque minerals and traces of calcite

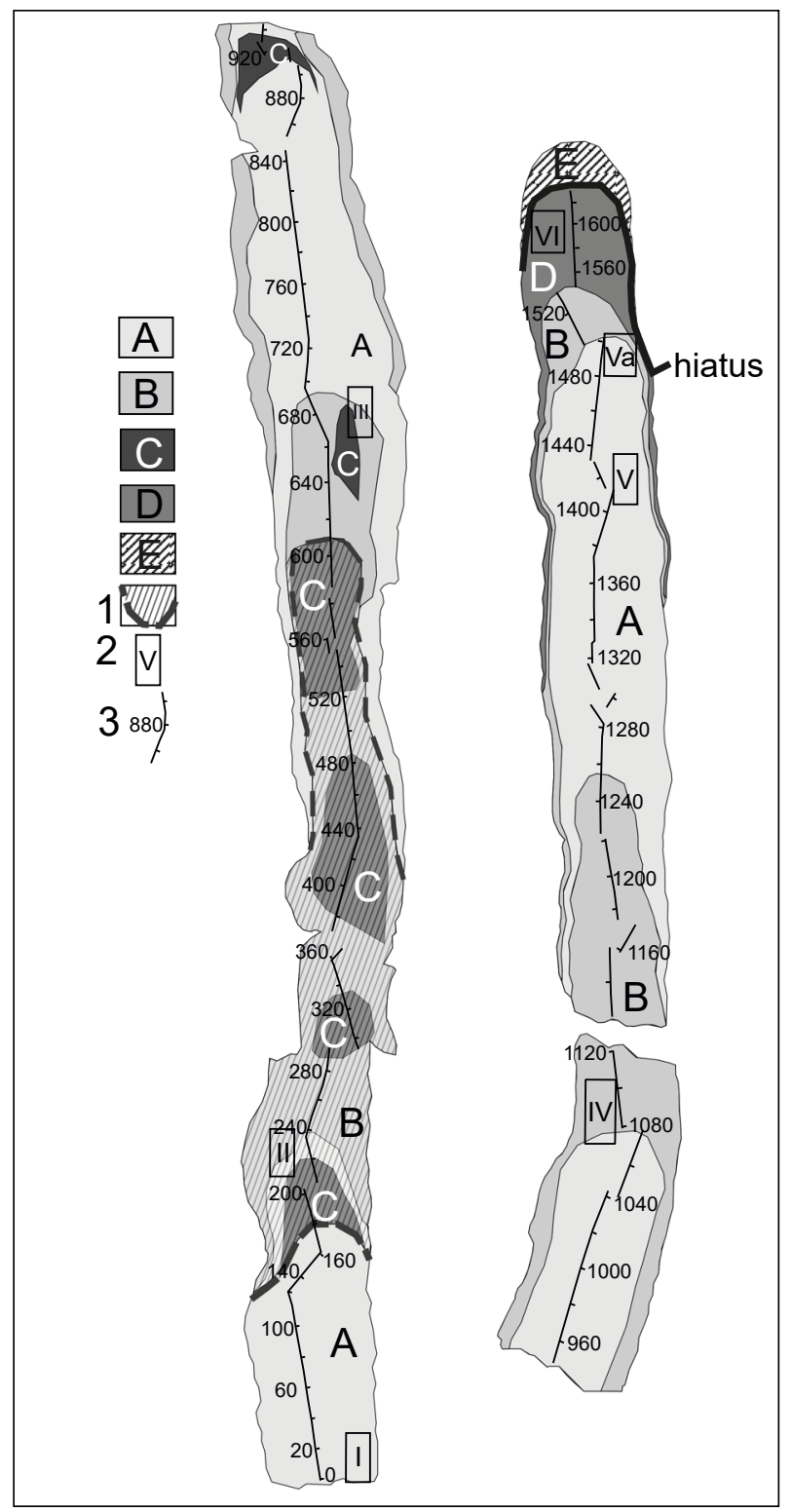

Fig. 2. Locations of identified calcite types in ocz-6 stalagmite. $A, B, C$ $D, E$ localization of five different types of calcite distinguished in ocz- 6 stalagmite 1 - The zone with disturbed U-series ages; 2 - Positions of thin sections; 3 - Stalagmite growth axis scale in $\mathrm{mm}$. 
crystals from younger generations are noticeable (Figs. 3E, 3F). The dominant microfabric is columnar open fabric. A portion of the stalagmite between 1,530 and $1,630 \mathrm{~mm}$ comprises type $\mathrm{D}$, a light yellow calcite with slightly visible lamination. These layers differ in their

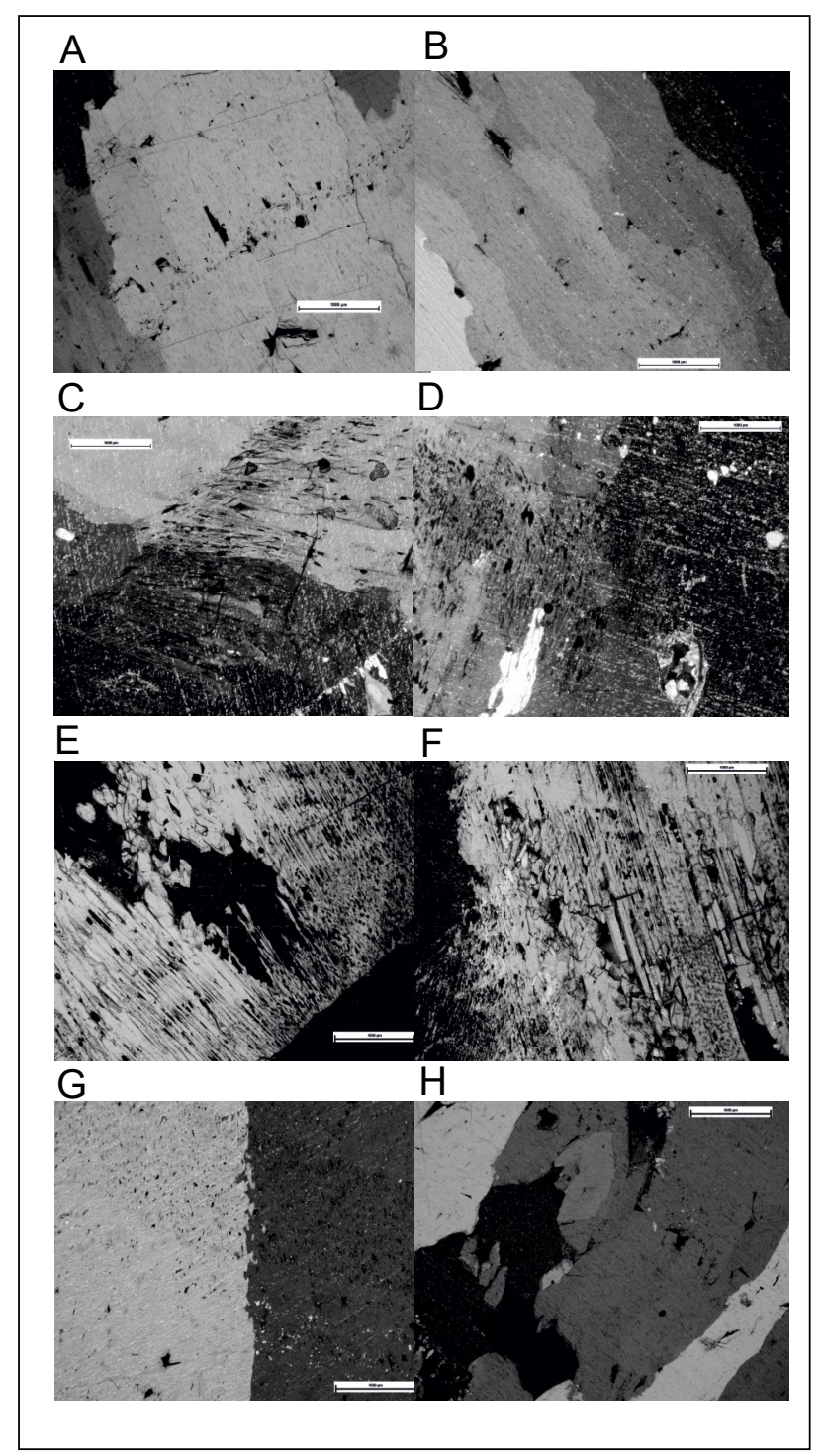

Fig. 3. Microscopic photos of ocz- 6 calcite types. $A, B$ - photos from thin section I, in which the observed columnar compact fabric is dominant, with narrow overlays of columnar open fabric; $C, D$ - photos from thin section II, in which observed fabrics are mainly alternating columnar open and columnar compact fabrics, and higher contents of detrital material were observed; $E, F$ - photos from thin section III, exhibiting a very strongly porous zone; the dominant fabric is columnar open fabric, and in some pores, the presence of opaque minerals and traces of secondary mineralization are noticeable; $G$ - photo from thin section $\mathrm{Vl}$; similar to photos $A$ and $B$, the dominant fabric is columnar compact fabric; $\mathrm{H}$ - photo from thin section $\mathrm{VI}$, documenting the transition zone between the columnar compact fabric and what is classified as columnar elongated fabric, where much thinner calcite crystals occur and the incomplete coalescence of crystals and a few impurity-rich layers were also observed. transparency and porosity. The dominant microfabrics are columnar open and columnar compact fabrics (Fig. 3G). In the upper part, a fabric similar to a columnar elongated fabric is visible (Fig. 3G). In the layer below the hiatus, numerous pores were identified, and some are filled with secondary calcite crystals. The part of the stalagmite above the hiatus at $1,630 \mathrm{~mm}$ comprises type $\mathrm{E}$, which is a light brown calcite containing the significant admixture of detrital material.

The characteristics mentioned above are similar to those described by Turgeon and Lundberg (2001), Frisia (2015), which indicates that columnar fabric is dominant in this stalagmite. Petrographic observations revealed the occurrence of several types of columnar fabrics: elongated crystals fabrics reflect competitive growth, with the incomplete coalescence of crystals and length to width ratios of greater than $6: 1$, which sometimes exhibit lateral overgrowth; compact fabrics form when the crystals form a compact aggregate and the intercrystalline porosity is no longer discernible; and open fabrics are characterized by the presence of linear inclusions or pores (Frisia, 2015).

\section{U-series}

Samples used for U-series dating were collected uniformly along the stalagmite growth axis. The analysis of the obtained results indicated a problem with the dating of the lower part of the stalagmite. For section from $c a$. 180 to $610 \mathrm{~mm}$ from the base dating results were scattered randomly in the range of $118-127 \mathrm{ka}$, with several age inversions. Detailed microscopic observations revealed numerous traces of secondary alterations and high secondary porosity with younger calcite fills in this zone (Fig. 3). Despite several attempts to precisely select material for analysis (e.g., using binocular microscopy), no reliable results were obtained from this part of the stalagmite. Therefore all dating result and other geochemical proxies from this part of stalagmite have been excluded from the further interpretation. Finally, a series of 13 reliable results were obtained from the non-porous part of the stalagmite. The U-series dating results are presented in Table 1. The reported errors represent 2 standard deviations and they vary from 1 to $2 \%$. Although no samples showed visible detrital contamination at the dissolution stage, the measured isotope ratios were corrected for minor amounts of initial $\mathrm{U}$ and Th using ${ }^{232} \mathrm{Th}$ as a contamination index. The modified Hellstrom (2006) algorithm has been used. In all cases, the corrected ages are within the error range of the un-corrected ages.

Based on the U-series dating results, an age-depth model (Fig. 4A) was created from the ocz-6 base at $0 \mathrm{~mm}$ to its hiatus at $1,630 \mathrm{~mm}$. Layer $\mathrm{E}$, which is located above the hiatus (Fig. 2), contains detrital material; thus, its dating is problematic. However, the archival U-series age (not included into main age-depth model) obtained by $\alpha$ spectrometry shows that the age of that layer is MIS 4 . The dates are shown as $2 \sigma$ error ellipsoids (based on MC 
Table 1. Results of the U-series dating of stalagmite from Orlova Chuka Cave. Reported errors are $2 \sigma$.

\begin{tabular}{|c|c|c|c|c|c|c|c|c|}
\hline $\begin{array}{l}\text { Lab } \\
\text { no }\end{array}$ & $\begin{array}{l}\text { Distance } \\
\text { from the } \\
\text { base } \\
(\mathrm{mm})\end{array}$ & $\begin{array}{l}\text { U cont. } \\
\text { (ppm) }\end{array}$ & ${ }^{234} U / 238 U$ & ${ }^{230} \mathrm{Th} /{ }^{234} \mathrm{U}$ & ${ }^{230} \mathrm{Th} /{ }^{232} \mathrm{Th}$ & $\begin{array}{l}\text { Age } \\
\text { (ka) }\end{array}$ & $\begin{array}{l}\text { Stratigra- } \\
\text { phically } \\
\text { corrected } \\
\text { age } \\
\text { (ka) }\end{array}$ & $\begin{array}{c}\text { Initial } \\
\text { corrected } \\
{ }^{234} \mathrm{U} / 238 \mathrm{U}\end{array}$ \\
\hline 252 & $45 \pm 1.5$ & $0.2247 \pm 0.0005$ & $1.022 \pm 0.004$ & $0.701 \pm 0.077$ & $582.2 \pm 6.1$ & $130.5 \pm 2.6$ & $130 \pm 2.5$ & $1.03 \pm 0.02$ \\
\hline 511 & $60 \pm 1.5$ & $0.2554 \pm 0.0008$ & $1.021 \pm 0.003$ & $0.686 \pm 0.009$ & $576 \pm 8$ & $125.1 \pm 3.0$ & $127.1 \pm 1.8$ & $1.03 \pm 0.02$ \\
\hline 253 & $79 \pm 1.5$ & $0.2388 \pm 0.0006$ & $1.028 \pm 0.004$ & $0.686 \pm 0.007$ & $1191.9 \pm 11.4$ & $125.0 \pm 2.2$ & $126.5 \pm 1.4$ & $1.03 \pm 0.02$ \\
\hline 249 & $178 \pm 1.5$ & $0.1705 \pm 0.0002$ & $1.022 \pm 0.003$ & $0.692 \pm 0.005$ & $109.3 \pm 0.8$ & $127.4 \pm 1.7$ & $126.1 \pm 1.3$ & $1.03 \pm 0.01$ \\
\hline 244 & $620 \pm 1.5$ & $0.2396 \pm 0.0003$ & $1.032 \pm 0.003$ & $0.691 \pm 0.004$ & $909 \pm 5$ & $126.5 \pm 1.3$ & $125.4 \pm 1.2$ & $1.045 \pm 0.013$ \\
\hline 245 & $760 \pm 1.5$ & $0.1876 \pm 0.0003$ & $1.036 \pm 0.003$ & $0.680 \pm 0.005$ & $587.5 \pm 3.7$ & $122.6 \pm 1.4$ & $122.5 \pm 1.5$ & $1.05 \pm 0.02$ \\
\hline 601 & $801 \pm 1.5$ & $0.1769 \pm 0.001$ & $1.049 \pm 0.004$ & $0.683 \pm 0.009$ & $34.2 \pm 0.5$ & $123.1 \pm 3.1$ & $121.8 \pm 1.7$ & $1.069 \pm 0.026$ \\
\hline 241 & $886 \pm 1.5$ & $0.2871 \pm 0.0003$ & $1.032 \pm 0.002$ & $0.676 \pm 0.003$ & $2631.9 \pm 12.3$ & $121.4 \pm 1.0$ & $120.8 \pm 1$ & $1.04 \pm 0.02$ \\
\hline 247 & $1029 \pm 1.5$ & $0.2235 \pm 0.0003$ & $1.022 \pm 0.003$ & $0.672 \pm 0.005$ & $794.6 \pm 0.5$ & $120.5 \pm 1.4$ & $120.3 \pm 1.1$ & $1.031 \pm 0.012$ \\
\hline 248 & $1182 \pm 1.5$ & $0.2101 \pm 0.0003$ & $1.024 \pm 0.003$ & $0.672 \pm 0.004$ & $164.5 \pm 1$ & $120.5 \pm 1.3$ & $119.9 \pm 1.2$ & $1.034 \pm 0.012$ \\
\hline 246 & $1264 \pm 1.5$ & $0.2495 \pm 0.0003$ & $1.036 \pm 0.002$ & $0.673 \pm 0.004$ & $858.4 \pm 5.7$ & $120.3 \pm 1.4$ & $119.3 \pm 1.3$ & $1.05 \pm 0.01$ \\
\hline 250 & $1380 \pm 1.5$ & $0.1589 \pm 0.0002$ & $1.045 \pm 0.003$ & $0.662 \pm 0.005$ & $116.8 \pm 1.5$ & $116.8 \pm 1.5$ & $115.8 \pm 1.5$ & $1.06 \pm 0.02$ \\
\hline 380 & $1540 \pm 1.5$ & $0.1597 \pm 0.0003$ & $1.024 \pm 0.003$ & $0.654 \pm 0.007$ & $204.5 \pm 2.1$ & $114.8 \pm 2.1$ & $114.2 \pm 2.1$ & $1.03 \pm 0.02$ \\
\hline
\end{tabular}

simulations; Hercman and Pawlak, 2012). Black lines represent the best age estimates, with outlying lines indicating the $2 \sigma$ uncertainty bands. According to the obtained age-depth model, the deposition of the stalagmite started ca. $129 \pm 1.5 \mathrm{ka}$, and growth termination occurred ca. $112 \pm 1.8 \mathrm{ka}$. The age-depth model obtained for the ocz-6 stalagmite shows several changes in the stalagmite growth rate (Fig. 4B) ranging from $65 \mathrm{~mm} / \mathrm{ka}$ to 350 $\mathrm{mm} / \mathrm{ka}$. Based on differences in the stalagmite growth rate, the 5 phases of its deposition can be distinguished (Fig. 4C). Phase 1 from $c a$. 129 to $c a$. $126.5 \mathrm{ka}$; phase 2 from $c a$. 126.5 to $c a .125 .5 \mathrm{ka}$; phase 3 from $c a$. 125.5 to ca. $121.5 \mathrm{ka}$; phase 4 from $c a$. 121.5 to $c a .119 .5$; phase 5 from $c a$. 119.5 to $c a$. 112 .

According to obtained age - depth model ocz- 6 stalagmite deposition rate was around $68 \mathrm{~mm} / \mathrm{ka}$ during most of the time of its crystallization (Figs. 4B, 4C). There are two periods of time $126.5-125.5 \mathrm{ka}$ and $121.5-119.5 \mathrm{ka}$, when deposition rate was higher up to $350 \mathrm{~mm} / \mathrm{ka}$. Based on differences in deposition rate, five stages of ocz- 6 deposition can be distinguished (Figs. 4B, 4C). Deposition rate is often used as an important factor controlling the development of the calcite micro-fabrics (Frisia et al., 2003). However their morphology is also controlled by combination of other factors like: supersaturation, impurity content, $\mathrm{Mg} / \mathrm{Ca}$ ratio in dripping water (Frisia et al., 2003). The ocz-6 stalagmite is built from three types of micro fabric: columnar compact, columnar open and columnar elongated in its upper part. The stages with slower deposition rate (1,3 and 5) are built mostly from columnar compact fabric which suggests calm calcite crystallization under the regime of constant drip rate (Figs. 3A, 3B). Situation changes during the stages with faster deposition rate (2 and 4). The stalagmite in stage 2 comprises highly porous columnar open fabric (type C); more porous zones are associated with the conditions of relatively fast and changing dripping rates (Figs. 3E, 3F). Pores contain younger generations of calcite crystals and detrital contaminants. This all suggest crystallization under dynamic conditions. Stage 4 is built from columnar compact and columnar open fabric. The level of porosity is lower here and there is no trace of secondary calcite crystallization inside the pores. Stage 4 represents the environment of more dynamic crystallization than stages 1 and 3 but not as dynamic as stage 2. The upper part of stage 5 comprises a columnar elongated fabric and contains more detrital material (Fig. 3H). In summary the observed calcite micro fabrics are in accordance witch calculated changes in stalagmite deposition rate. The stages 2 and 4 records time of faster dripping rate than stages 1,3 and 5 .

\section{Stable Isotopes}

The isotopic records $\left(\delta^{18} \mathrm{O}, \delta^{13} \mathrm{C}\right)$ along the growth axis have a mean temporal resolution of $0.022 \mathrm{ka}$.

Both the $\delta^{18} \mathrm{O}(-6.9 \%$ to $-12.3 \%)$ and $\delta^{13} \mathrm{C}(0.5 \%$ to $-10 \%$ ) records exhibit significant variation. The oxygen $\delta^{18} \mathrm{O}$ record (Fig. 5, black line) starts with a decreasing main trend from $c a .129 \mathrm{ka}$ to $127,5 \mathrm{ka}$, with an average decrease of approximately $-0.15 \% / \mathrm{ka}$. From $\mathrm{ca} .127 .5 \mathrm{ka}$ to $126.2 \mathrm{ka}$, it strongly increases by $+0.8 \% / \mathrm{ka}$. After the porous zone from $\mathrm{ca}$. $125,3 \mathrm{ka}$ to $112,8 \mathrm{ka}$, it exhibits a decreasing trend, the average decrease is approximately $0.25 \% / \mathrm{ka}$. At the end of the record, the signal grows rapidly. In addition to the main trend, the $\delta^{18} \mathrm{O}$ record has a second-order signal with average amplitude of approximately $0.85 \%$. The $\delta^{13} \mathrm{C}$ record (Fig. 5, gray line) starts by decreasing with an average rate of decrease of approximately $-0.15 \% / \mathrm{ka}$; from $c a .125 \mathrm{ka}$ to $c a .121 \mathrm{ka}$, it has stable mean value ca $-11.4 \%$; from $c a$. $121 \mathrm{ka}$ to $112.8 \mathrm{ka}$, this trend increases with an average increase of approximately $0.3 \% / \mathrm{ka}$; at the end of the record, the 


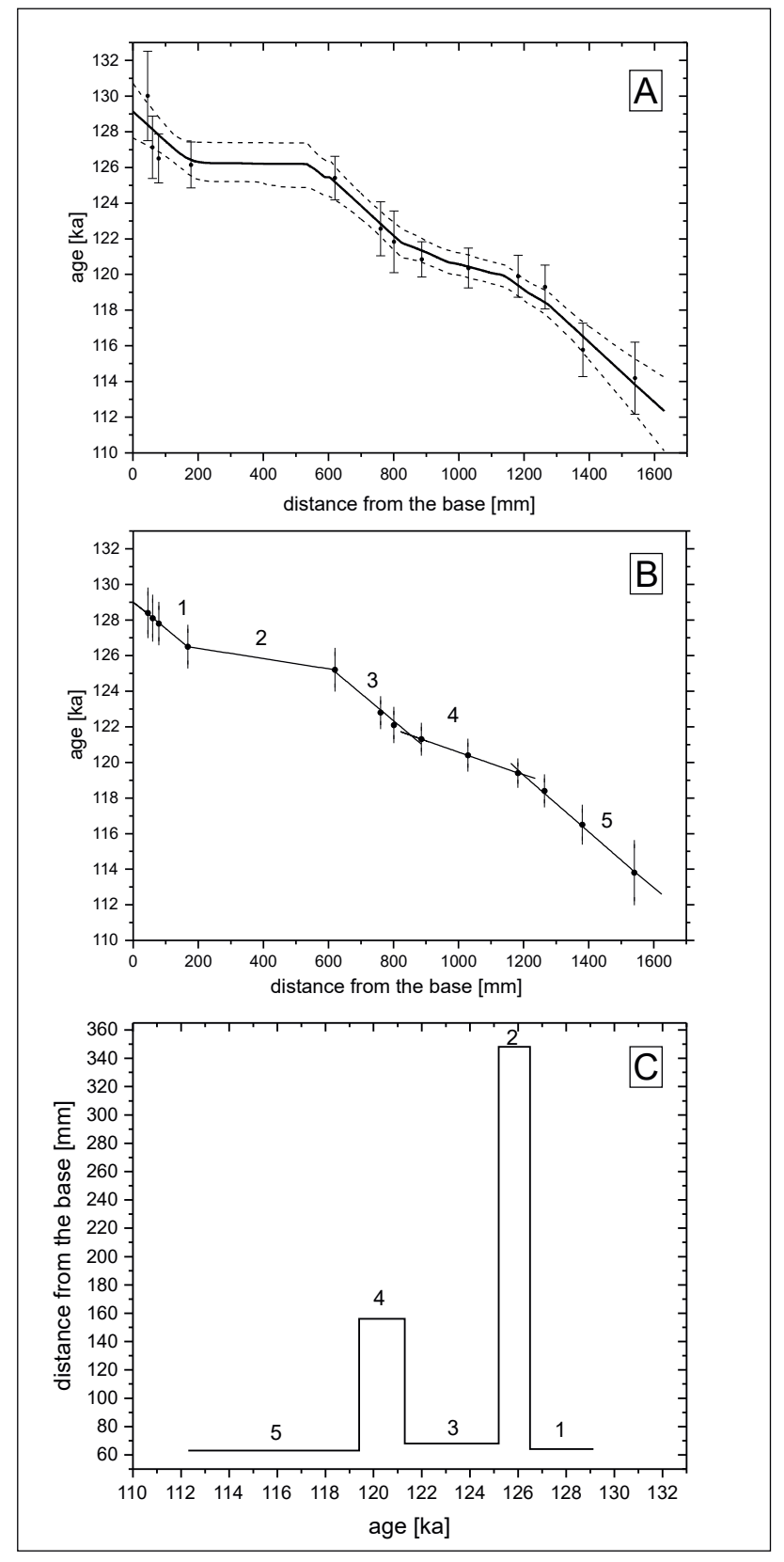

Fig. 4. Results of U-series dating. $A$ - Age-depth model; $B$ - Linear approximation of deposition stages; $\mathrm{C}-\mathrm{O}$ cz- 6 stalagmite growth rate; $1,2,3,4,5$ - Distinguished phases of stalagmite deposition with corresponding growth rate estimations.

signal grows rapidly. Similar to the $\delta^{18} \mathrm{O}$ record, the $\delta^{13} \mathrm{C}$ record has millennial-scale fluctuations with average amplitude of approximately $1.5 \%$ and centenary-scale fluctuations with average amplitude of approximately $0.4 \%$.

\section{Trace elements}

Trace element profiles were measured along the stalagmite growth axes in six (I - VI) thin sections (Fig. 6). According to the age-depth model (Fig. 4A), the obtained

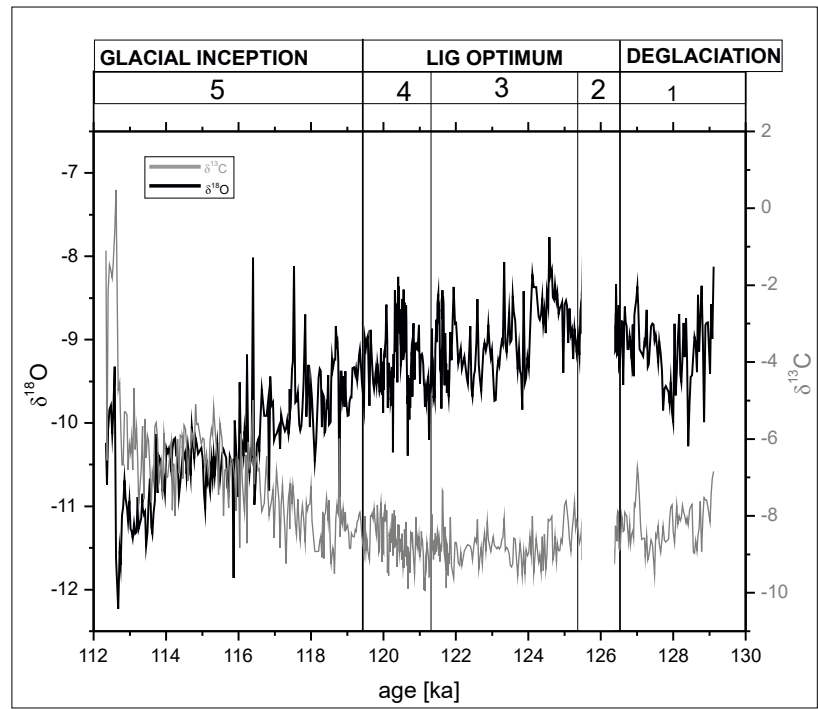

Fig. 5. $\delta^{18} \mathrm{O}$ (black line) and $\delta^{13} \mathrm{C}$ (gray line) records from the ocz-6 stalagmite. 1, 2, 3, 4, 5-Distinguished phases of stalagmite deposition.

trace element profiles cover six time intervals: I (129,2-128.3 ka); II (126.29-126.24 ka); III (124.35$123.5 \mathrm{ka})$; IV (120.25-119.95 ka); V (116.15-115.35 ka); and VI (113.8-112.7 ka). Interpretation of profile II is omitted because it covers the porous zone. During the primary assess ment of trace element results we observed, that elements like: $\mathrm{Mn} ; \mathrm{Zn} ; \mathrm{Cu}$ and $\mathrm{Ni}$ repeats the $\mathrm{Fe}$ pattern, while $\mathrm{Al}$ and $\mathrm{Zr}$ behaves similarly to Si. Concentration of elements like $\mathrm{U}$ and $\mathrm{Th}$ was relative low and was dominated by the noise signal. Therefore we decided to take account only the clearly inked with environmental conditions: $\mathrm{Sr} ; \mathrm{Mg}$; $\mathrm{P}$; $\mathrm{Na}$, and $\mathrm{Fe}$, $\mathrm{Si}$ results which are representative for other elements.

$\mathrm{Sr}$ content oscillates around 0.01 value in all measured profiles. In contrast to $\mathrm{Sr}$, magnesium content changes more rapidly, its value oscillates between 0.01 and 0.1. Except the profile VI, $\mathrm{Sr}$ and $\mathrm{Mg}$ contents are in weak anti correlation mostly. Fe content in ocz- 6 changes rapidly from 0.001 to 0.1 value. The $\mathrm{Fe}$ content at the beginning (profile I) and at the end of ocz- 6 stalagmite (profile VI) is in correlation with $\delta^{13} \mathrm{C}$ (Fig. $6 \mathrm{~V}$, VII). Amplitude of $\mathrm{P}$ content changes is lower than amplitude of $\mathrm{Fe}$ content changes. However it seems to repeat the same pattern as Fe (Fig. 6).

\section{DISCUSSION}

\section{Suitability assessment of the ocz-6 stalagmite}

Cave stalagmites are suitable source of paleoenvironmental data. However, stalagmite material must meet several requirements. First, speleothem calcite should precipitate under isotopic equilibrium conditions. Hendy tests are the classical tests used to ascertain whether equilibrium conditions were achieved during calcite precipita- 


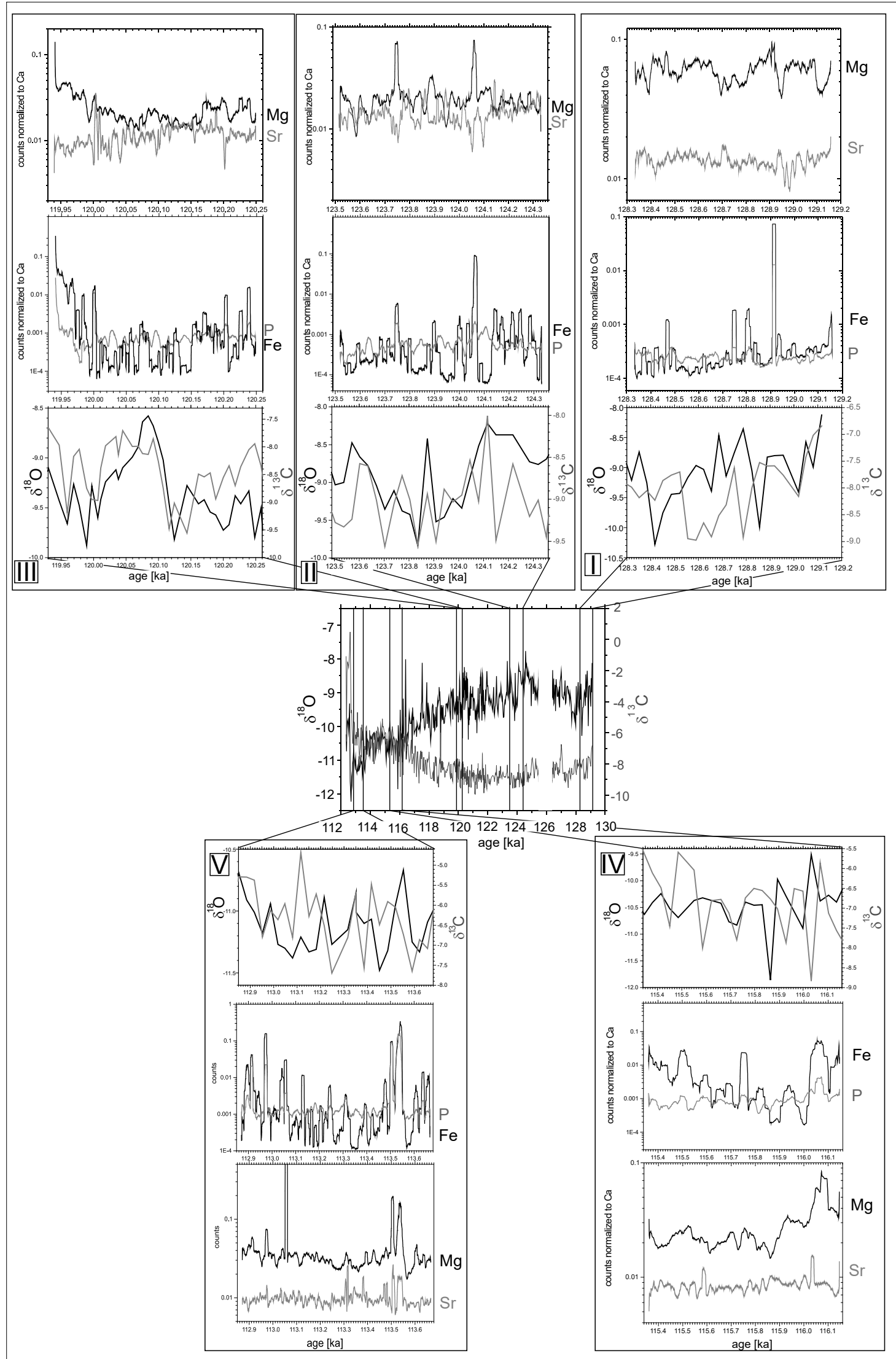

Fig. 6. Trace element profiles from thin - sections I, III, IV, V description in the text. 
tion (Hendy and Wilson, 1968; Hendy, 1971). However, Hendy's criteria have been revised (Dorale and Liu 2009). The concept of criterion (1) of the Hendy Test, sampling along a single growth layer may be flawed in both theory and practice. But the assumption that growing axis (central part of stalagmite) has higher probability for equilibrium conditions than flanks part of stalagmite remains true. Criterion (2) of the Hendy Test is based on the assumption that speleothem $\delta^{13} \mathrm{C}$ values react in a different way than $\delta^{18} \mathrm{O}$ values in response to climate changes. That assumption is not always correct. Dorale and Liu (2009) proposed replication test instead of Hendy's Criterions. We were not able to made control isotopic profile from another stalagmite of the same age because of lack of suitable material from Orlova Chuka Cave. However results of classic Hendy's Criterions shows no traces of disequilibrium for ocz-6 stalagmite (see supplementary Fig. S1).

The second requirement is that the stalagmite porosity should be low. Pores may contain younger generations of calcite or admixtures of detrital material. Both may disturb the measurement of uranium and thorium isotopic compositions, which can yield incorrect U-series ages. Macroscopic and microscopic analyses show that the ocz6 stalagmite comprises elongated calcite crystals, which range from approximately $0.2 \mathrm{~mm}$ to $5 \mathrm{~mm}$ in width and $2 \mathrm{~mm}$ to $40 \mathrm{~mm}$ in length, and the porosity of these layers is low (Figs. 3A, 3B). However, there are zones (type C; Fig. 2) that have higher porosities visible on a macroscopic scale; most C-type calcite is located between 180 and $610 \mathrm{~mm}$ from the base (Fig. 2). Thus, any geochemical proxy from this part of the stalagmite should be interpreted with care. Therefore we decided to exclude all geochemical data (including the U-series ages) from this part of the record. Fortunately the age-depth model estimated for the ocz- 6 stalagmite shows that this $430-\mathrm{mm}$ long zone formed in less than $1 \mathrm{ka}$.

\section{Factors influencing on oxygen isotopic composition in calcite}

The $\delta^{18} \mathrm{O}$ value of speleothem calcite depends on $\delta^{18} \mathrm{O}$ of dripping water and temperature in the cave. The $\delta^{18} \mathrm{O}$ of dripping water depends on the source of moisture, its transportation, the intensity of atmospheric precipitation and temperature (Darling, 2004; Lachniet, 2006). At the precipitation site the isotopic composition is modified by local conditions like temperature and amount of rainfall. However, meteorological observations show that in temperate regions of Europe, temperature changes have a stronger effect on precipitated water $\delta^{18} \mathrm{O}$ than changes in the amount of rainfall (Różański at al., 1993).The thermal gradient for calcite crystallization $\left(\delta^{18} \mathrm{O}_{\mathrm{ct}} / \mathrm{dt}\right)$ varies from -0.18 to $-0.23 \%$, while the thermal gradient for the $\delta^{18} \mathrm{O}$ of precipitated water $\left(\delta^{18} \mathrm{O}_{\mathrm{p}} / \mathrm{dt}\right)$ ranges from +0.17 to $+0.9 \%$ o (Dansgaard, 1964; Różański et al., 1993; Lachniet, 2006). Therefore, the speleothem $\delta^{18} \mathrm{O}$ response to temperature is strongly site-dependent (Gascoyne, 1992;
Dorale et al., 1998; Williams et al., 1999; Mangini et al., 2005). Observations from located in southern Romania Isverna Cave (Dragusin et al., 2017) show that present mean value for crystalizing speleothem calcite, in the region, is close to $-8 \%$. Present data from Isverna Cave have higher values of $\delta^{18} \mathrm{O}$ for calcite crystalizing in warmer months, it shows that thermal gradient for the $\delta^{18} \mathrm{O}$ in water is more important for a region. The $\delta^{18} \mathrm{O}$ value for local meteoric water changes from $-15 \%$ in December to $-4 \%$ in April (Dragusin et al., 2017). However April is not the warmest month in a region. Therefore fact that the April rain water has the maximal value of $\delta^{18} \mathrm{O}$ shows that not only the temperature but also other factors like the source of moisture and the way of its transportation plays the important role in shaping of $\delta^{18} \mathrm{O}$ composition of rain water here. Additionally this seasonal difference shows how strongly the mean year isotopic composition depends from the amount of rainfall during the seasons. Presently, the main source of moisture for a region is Atlantic on the west, a small amount of moisture is also transported from Mediterranean region on the south. The other possible sources are Black sea on east and norther sources like White and Norwegian Sea. (Malcheva et al., 2015; Dragusin et al., 2017; Nojarow, 2018). Dragusin et al. (2017) describes the abnormal heavy values of $\delta^{18} \mathrm{O}$ in rain for December, which was caused by complicated way of moisture transportation and accumulation of enriched in $\delta^{18} \mathrm{O}$ Mediterranean vapor. The Atlantic moisture can be depleted in $\delta^{18} \mathrm{O}$ because of lower average annual temperatures at evaporation site and longer, than for Mediterranean, way of transportation (continental effect).

\section{Interpretation of climate conditions on the basis of geochemical data from ocz-6 stalagmite}

The ocz- $6 \delta^{18} \mathrm{O}$ records starts with negative $\delta^{18} \mathrm{O}$ trend (Fig. 5). Since the temperature drop is not expected at the beginning of interglacial, the negative $\delta^{18} \mathrm{O}$ trend observed in ocz-6 record from ca. 129 to $c a$. $127.5 \mathrm{ka}$ (Fig. 5) can be associated with changes in proportion of amount of moisture from different sources and may reflects continuous increase of depleted in $\delta^{18} \mathrm{O}$ moisture of Atlantic origin.

The decreasing $\delta^{13} \mathrm{C}$ trend, at that time, can be interpreted as a period of continuously increasing of soil activity what is expected at the beginning of interglacial period. Changes in vegetation cover and amount of rainfall is supported by trace elements content. The $\mathrm{Mg}$ and $\mathrm{Sr}$ content in speleothem calcite depend on factors like amount of rainfall and the water residence time. In the older part of the record, $\mathrm{Mg}$ and $\mathrm{Sr}$ exhibit weak anticorrelation. After $128.9 \mathrm{ka}$, several Mg peaks are in phase with Sr peaks (I; Fig. 6), it may suggest climatic cycles from wetter to dryer periods, when prior calcite precipitation was more intensive. The trace element profile (I; Fig. 6) shows systematic decreases in the $\mathrm{Fe}$ content. This trend is correlated with the $\delta^{13} \mathrm{C}$ decreasing trend. The $\mathrm{P}$, 
Si and Na content (see supplementary Fig. S2) were lower during the time interval from 129.1 to $128.9 \mathrm{ka}$ (Fig. 6I). In general, the Si content in drip waters are controlled by the supply of wind-blown silicates, the weathering rate, rainfall dilution, and the growth rate of calcite. A high $\mathrm{Si} / \mathrm{Ca}$ ratio suggests dry climatic conditions (Geilert et al., 2014). After $128.9 \mathrm{ka}$, the Si and Na contents become stable, and the $\mathrm{P}$ content begins to increase. The main source of $\mathrm{P}$ is soil (Treble et al., 2003). During an interglacial period, changes in $\mathrm{P}$ content are usually interpreted as an indicator of changes in atmospheric precipitation (Treble et al., 2003). More intensive precipitation flushes more $\mathrm{P}$ out of the soil. However, during the developing phases of interglacial conditions, a systematic increase in the $\mathrm{P}$ content during a time of hundreds years can be interpreted as soil development indicator. This interpretation is in agreement with decreasing $\delta^{13} \mathrm{C}$ value (Fig. 5).

The positive shift for the $\delta^{18} \mathrm{O}$ value observed during the interglacial optimum $c a .125 \mathrm{ka}$ can be interpreted as the improvement of thermal conditions. Since $127.5 \mathrm{ka}$ to ca. 121 ka the $\delta^{13} \mathrm{C}$ has the lowest values. Low $\delta^{13} \mathrm{C}$ values and elevated $\delta^{18} \mathrm{O}$ indicate optimum climate conditions with warm temperatures, increased year-round precipitation and high soil biogenic activity. However, there are few indicators of climate instability during this period of time. The $\delta^{18} \mathrm{O}$ values fluctuate from $-7.8 \%$ to $-9.8 \%$. This short time changes are in phase with $\delta^{13} \mathrm{C}$ value changes. The events of lower $\delta^{13} \mathrm{C}$ values may suggest a faster rate of water seepage, which is a consequence of higher rainfall. Short time periods of low $\delta^{18} \mathrm{O}$ values suggests temperature drop during the wetter periods. Records of $\mathrm{Sr}$ and $\mathrm{Mg}$ content from climatic optimum are in anti-correlation mostly (II: Fig. 6). Thus may be indicator of increased rainfall and lack of priori calcite precipitation events at that time. It suggest wetter interglacial optimum than developing phase (II, III: Fig. 6).

Negative main trend for $\delta^{18} \mathrm{O}$ visible since $c a .124 \mathrm{ka}$, can be interpreted as slow decreasing of mean annual temperature. From $121 \mathrm{ka}$ the $\delta^{13} \mathrm{C}$ value starts to grow, which is indicator of lowering soil activity. The increasing of $\delta^{13} \mathrm{C}$ value and decreasing $\delta^{18} \mathrm{O}$ suggest systematic worsening of environmental conditions. At that time that the like during interglacial optimum there are short time fluctuations of $\delta^{18} \mathrm{O}$ which are in phase with $\delta^{13} \mathrm{C}$ value changes. However amplitudes of those changes are higher up to $2.1 \%$ (Fig. 5), which suggests higher climate instability. The trace element profile shows elevated values of $\mathrm{Sr}, \mathrm{Mg}$ and $\mathrm{Fe}$ contents at $116.1 \mathrm{ka}$. This pick of elevated trace element content corresponds to both $\delta^{13} \mathrm{C}$ and $\delta^{18} \mathrm{O}$ fluctuations, which are not in phase (Fig. 6 V). A similar event of elevated $\mathrm{Fe}, \mathrm{P}$, and $\mathrm{Mg}$ contents is visible at 113.5 ka (Fig. 6 VI). Evidence of such events suggests an environment with reduced vegetation cover, which can cause a low level of retention. Therefore, increased rainfall could generate a rapid increase of water inflow into the cave. Three trace element profiles (IV, V and VI) are associated with interglacial demise period (Fig. 6). The mean $\mathrm{Fe}$ content along those three profiles increases from 0.003 to 0.0121 . The increased Fe content here may be the effect of increased weathering caused by soil degradation process. The reduction of vegetation cover under wet climatic conditions may indicate an increase of soil erosional processes. Similar Fe behavior connected with changes in $\mathrm{P}$ and Si content can be observed during stage 1 .

The strong positive shift $\delta^{18} \mathrm{O}$ observed since $113 \mathrm{ka}$ (Fig. 5) is connected with similar shift on $\delta^{13} \mathrm{C}$. The $\delta^{13} \mathrm{C}$ proxy can be interpreted in the context of soil activity. The elevation in $\delta^{13} \mathrm{C}$ values is indicator of lower soil activity. The $\delta^{18} \mathrm{O}$ enrichment, in this specific case, can be interpreted as effect of higher evaporation due to dryer conditions. Therefore highly elevated values of $\delta^{13} \mathrm{C}$ and $\delta^{18} \mathrm{O}$ may be indicators of dryer climate which lead to final stop of calcite crystallization at $c a .112 .5 \mathrm{ka}$.

Geochemical records discussed here represents the period of time from 129 to $112.5 \mathrm{ka}$. They show early stage of interglacial with systematic soil development. Its rather warm and wet optimum with noticeable climatic instability, connected with more wet and dry periods. The data shows slow worsening of thermal conditions since ca. $124 \mathrm{ka}$ and slow degradation of soil since $c a .121 \mathrm{ka}$.

\section{Comparison of data from ocz-6 stalagmite with other LIG records and global proxies}

The number of LIG speleothem isotopic records from Europe and the Middle East is still low, and only several of them cover the entire LIG period (Linge et al., 2001; Holzkamper et al., 2004; Drysdale et al., 2005, 2009; Munoz-García et al., 2007; Meyer et al., 2008; Couchoud et al., 2009; Boch et al., 2011; Genty et al., 2013; Regattieri et al., 2014; Moseley et al., 2015; Vansteenberge et al., 2016; Demeny et al., 2017). Ocz-6 stalagmite (Figs. 7C, 7D) starts to grow at similar time like the most of the LIG stalagmites from Central and Western Europe (Demeny et al., 2017; Couchoud et al., 2009). In its older part, before $126.5 \mathrm{ka}$, the ocz- $6 \delta^{18} \mathrm{O}$ record has a similar trend as Mediterranean records, with a small decreasing trend till $127.5 \mathrm{ka}$ and the lowest point close to $127.5 \mathrm{ka}$ (Fig. 7A), while the Alpine $\delta^{18} \mathrm{O}$ records have opposite to ocz-6 $\delta^{18} \mathrm{O}$ record trend (Fig. 7E). At that time, the oxygen isotopic composition in the Alpine records was controlling by the proportion between water from glacier source and water from the rain source, which explain the lowest values at the begging of most from Alpine records (Moseley et al., 2015).

During the LIG optimum, the ocz- $6 \delta^{18} \mathrm{O}$ record has similar trend as records from western and eastern regions of Europe (Fig. 7). All those record show the clear picture of the time period, associates with LIG optimum, where regional differences become less important. The beginning of LIG optimum is characterized by increase in the $\delta^{18} \mathrm{O}$ values of the ocz-6 record (Fig. 7A), which corresponds with reaching of full interglacial conditions in Greece at that time, what was reconstructed basing on paleontological profile of the Ioannina basin (Tzedakis, 


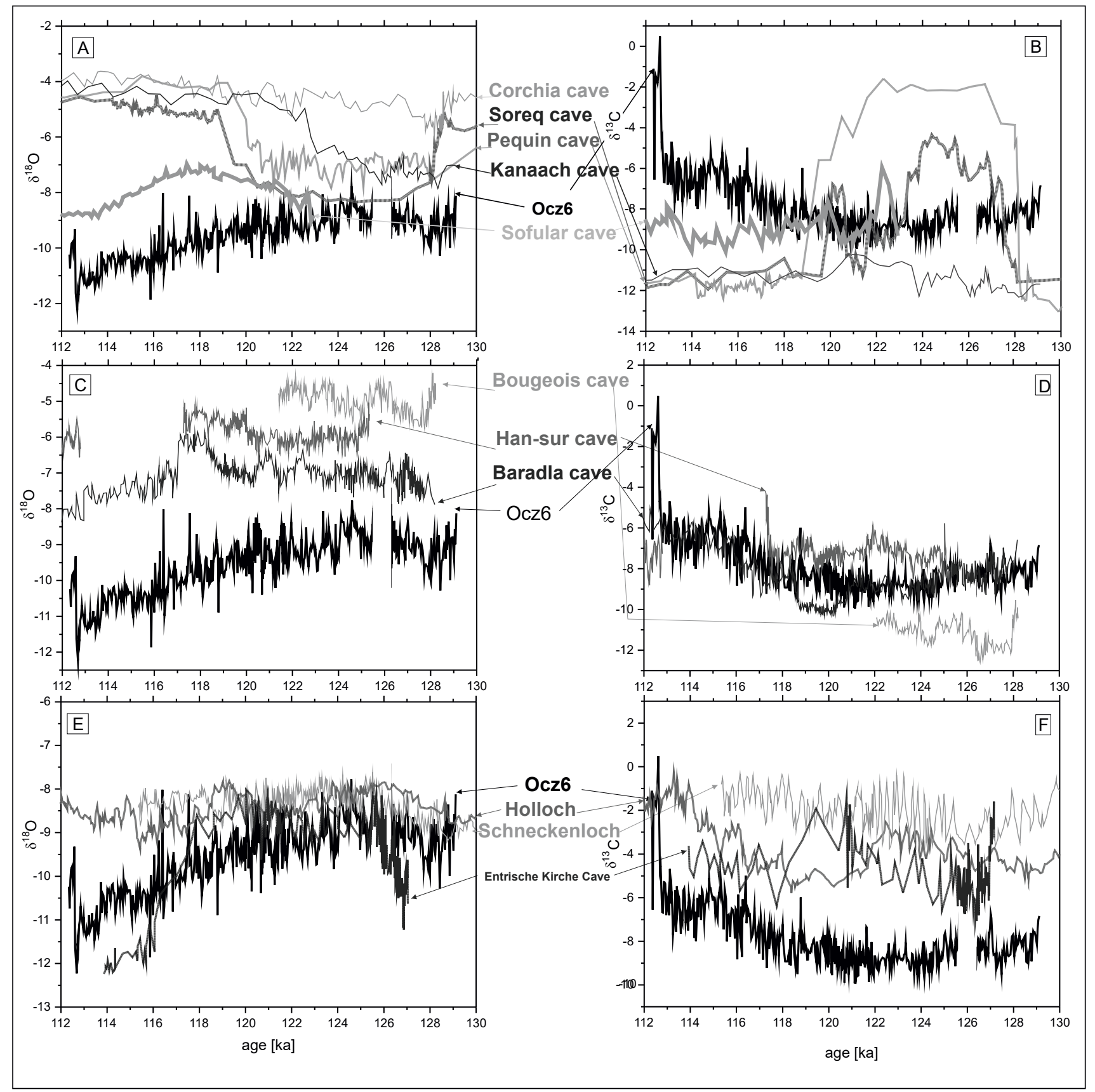

Fig. 7. Comparison of ocz- 6 isotopic records with other $L I G$ speleothem records: $A-\delta^{18} \mathrm{O}$ records from the Mediterranean region; $B-\delta^{13} C$ records from the Mediterranean region (Bar-Matthews et al., 2003; Drysdale et al., 2005; Zumbühl, 2010; Nehme et al., 2015); C - $\delta^{18} \mathrm{O}$ records from Western and Central Europe; $D-\delta^{13} \mathrm{C}$ records from Western and Central Europe (Couchoud et al., 2009; Vansteenberge et al., 2016; Demeny et al., 2017); $E-\delta^{18} \mathrm{O}$ records from the Alps; $F-\delta^{13} \mathrm{C}$ records from the Alps (Holzkamper et al., 2004; Meyer et al., 2008; Moseley et al., 2015).

1994). Additionally foraminifera record from sediment core located in the Western Mediterranean Sea shows warm and probably humid event with maximum at about $125 \mathrm{ka}$ (Kandiano et al., 2014). Pollen data analyze from a Black Sea region suggests well developed interglacial climate, for the period of time from 126.4 to $122.9 \mathrm{ka}$, with higher summer temperatures and mild winters. Typical interglacial thermal conditions were connected with higher annual precipitation (Shumilovskikh et al., 2013). Those data corresponds with positive shift for $\delta^{18} \mathrm{O}$ record of ocz-6 stalagmite. Data from Tenaghi Philippon peatland (NE Greece) suggested increased seasonality with arid summers and wet winters for the period of 128 to $123 \mathrm{ka}$ (Milner et al., 2013). The $\delta^{13} \mathrm{C}$ behavior in ocz-6 stalagmite and stalagmites from East Mediterranean region is different. At the LIG optimum time, most of East 
Mediterranean stalagmites have elevated $\delta^{13} \mathrm{C}$ values (Figs. 7A, 7B). The elevated $\delta^{13} \mathrm{C}$ values here reflect arid conditions (Drysdale et al., 2005; Bar-Matthews et al., 2003). In opposition during LIG optimum period, the ocz-6 record has low $\delta^{13} \mathrm{C}$ value which, together with $\delta^{18} \mathrm{O}$ and trace elements data, suggests humid conditions. The data from Western Europe suggest the climate instability during LIG optimum. Isotopic data from Southern France (Figs. 7C, 7D) are interpreted as fluctuations between wetter and dryer periods (Couchoud et al., 2009). Isotopic record from the Belgian Hansur-Lesse Cave shows similar humidity fluctuation in a period of time from 128 to $121 \mathrm{ka}$ (Vansteenberge et al., 2016). This climate instability is in accordance with the $\delta^{18} \mathrm{O}$ and $\delta^{13} \mathrm{C}$ fluctuations observed in ocz-6 record at that time.

Around $125 \mathrm{ka}$, the isotopic difference between the $\delta^{18} \mathrm{O}$ record from Hungarian Baradla Cave and ocz- $6 \delta^{18} \mathrm{O}$ records was the lowest, $c a$. $1 \%$. At that time the amount of rain precipitation from Atlantic source of moisture was probably high. Therefore we can expect continental effect on the line from west to east. Thus one per mille difference on the distance between Baradla and Orlova Chuka caves can be explained by the continental effect. Value of $1 \%$ on the distance $c a .500 \mathrm{~km}$ is in accordance with presently observed values of continental effect for Europe (Dansgaard, 1964). After the $124 \mathrm{ka}$, the isotopic shift between the Baradla and ocz- 6 records increased slowly to almost $2.5 \%$ at $118 \mathrm{ka}$, while the isotopic difference between the Baradla $\delta^{18} \mathrm{O}$ record and the Western European records remained stable (Fig. 7C). After $124 \mathrm{ka}$, the trends of the ocz- $6 \delta^{18} \mathrm{O}$ record and Mediterranean slowly changes and become opposite. After the LIG optimum the difference between $\delta^{18} \mathrm{O}$ trend from ocz-6 record and Alpine record are the lowest. Both carbon and oxygen isotope record of ocz- 6 stalagmite has a similar trend as the Alpine records. This suggests that the similar changes of climatic and vegetation conditions occurred in both regions.

The mechanism of increasing difference in $\delta^{18} \mathrm{O}$ composition, after the LIG optimum, between Western Europe, Alpine region, Ruse province and Mediterranean area is not clear. Baradla $\delta^{18} \mathrm{O}$ and $\delta^{13} \mathrm{C}$ records have a positive isotopic shift of approxi mately $1 \%$ at the same time (Fig. 7C). This positive isotopic shift is interpreted as a dry period (Demeny et al., 2017). Record from Eifel maar lake (Germany) shows strong aridity pulse around $118.5 \mathrm{ka}$ (Sirocko et al., 2005). It corresponds with has higher amplitude fluctuations of ocz-6 isotopic records between 119-116 ka.

The beginning of the LIG (Fig. 8) was characterized by increasing global sea level and summer insolation at $45 \mathrm{~N}$ (Dutton and Lambeck, 2012; Masson-Delmotte et al., 2013). Whole $\delta^{13} \mathrm{C}$ record from ocz-6 stalagmite reflects the insolation data in the $45 \mathrm{~N}$ record (Fig. 8C), which is connected witch vegetation changes occurred during interglacial development, its optimum and demise. At the beginning of LIG optimum the $\delta^{18} \mathrm{O}$ GRIP record

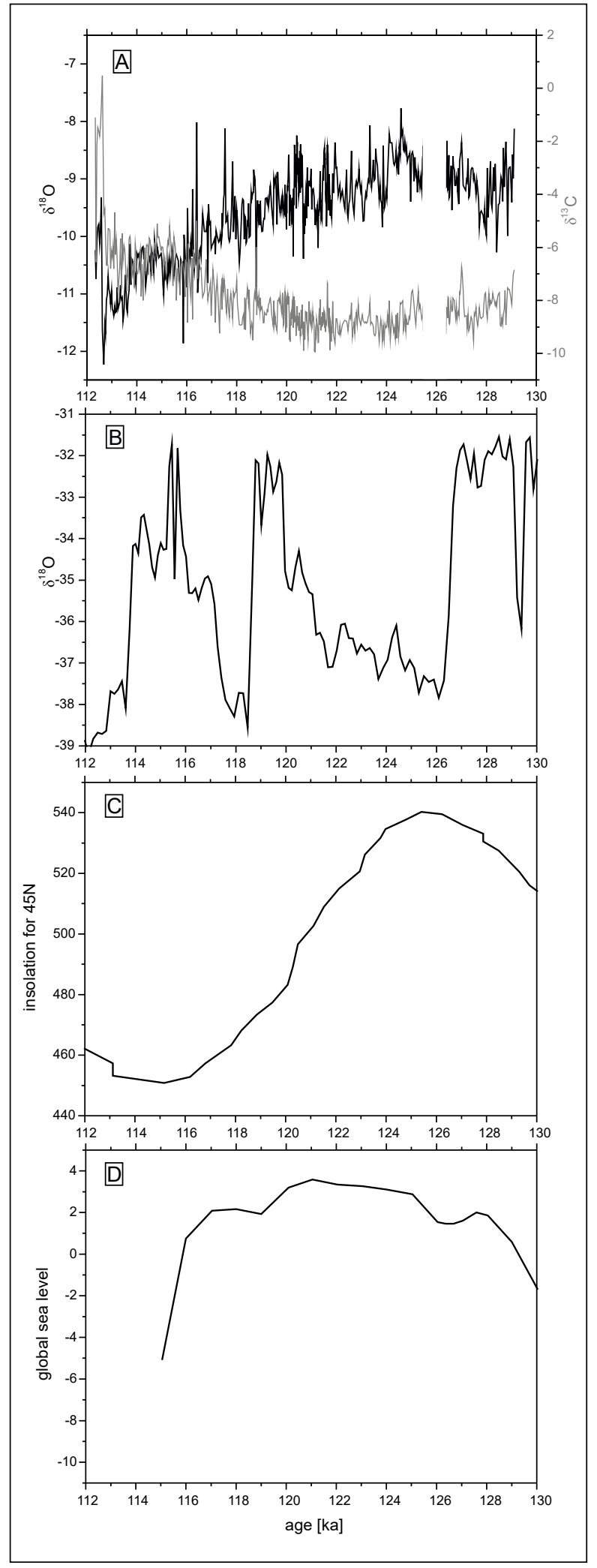

Fig. 8. Comparison of ocz-6 isotopic records with global proxies: $A-\delta^{18} O$ and $\delta^{13} C$ records from ocz- 6 stalagmite; $B-\delta^{18} O$ record from GRIP core (Chappellaz et al., 1997); C - Summer insolation for $45 \mathrm{~N}$ (Davis and Brewer, 2008); D - Global sea level (Dutton and Lambeck, 2012). 
shows a rapid decrease of $c a$. $6 \%$. It corresponds with the recording period of rapid stalagmite grow stage II in ocz6 stalagmite. The low values of $\delta^{18} \mathrm{O}$ GRIP record correspond with whole LIG optimum (Fig. 8B). The strong fluctuations of the GRIP record value after $120 \mathrm{ka}$ are probably coincident with the widespread ice rafting in the North Atlantic occurring at that time (Oppo et al., 2006; Müller and Kukla, 2004). Ice rafting on North Atlantic could slow down the North Atlantic Current (Müller and Kukla, 2004). This period of time is associated with influxes of depleted in ${ }^{18} \mathrm{O}$ water (Chappellaz et al., 1997), which is recorded in GRIP $\delta^{18} \mathrm{O}$ record (Fig. 8B).This period of time is connected with observed in ocz-6 $\delta^{18} \mathrm{O}$ record higher amplitude fluctuations between 119-116 ka. Recent data interpretation of the early LIG suggests lower than present temperature for the North Atlantic (Stone et al., 2016). Therefore observed differences between Alpine record, ocz-6 and Mediterranean records can be explained by stronger influence of other than Atlantic sources of moisture in the eastern part of the continent. From the other hand observed differences in isotopic records may be caused by different thermal changes in the regions or influence of evaporation especially in Mediterranean region and waters from glacial source in Alps (Moseley et al., 2015). After $116 \mathrm{ka}$, the $\delta^{18} \mathrm{O}$ records from ocz- 6 stalagmite and from most of European stalagmites, exhibits decreasing trends, while the $\delta^{13} \mathrm{C}$ values in those records increase. This reflects global cooling and changes in vegetation cover during the ending part of the interglacial.

\section{FINAL CONCLUSIONS}

The ocz-6 stalagmite grew from $c a .129$ to $c a .112 \mathrm{ka}$. The changes in $\delta^{13} \mathrm{C}$ for ocz- 6 stalagmite seem to reflect the development of soil and vegetation cover. The $\delta^{18} \mathrm{O}$ proxy probably reflects the thermal changes and the changes of moisture sources as well. During the time of interglacial development (129-126.5 ka), the ocz-6 $\delta^{18} \mathrm{O}$ trend was similar to Mediterranean $\delta^{18} \mathrm{O}$ records. Observed at that time negative trend is rather not connected with thermal changes, as we do not expect temperature drop at the interglacial beginning, therefore it rather suggests similar changes in sources of moisture for both regions. The crystallization of calcite occurred under stable regime at that time. Local conditions were dominated by periods of dryer and wetter climate, which is supported by changes in $\mathrm{Mg}$ and $\mathrm{Sr}$ content. Changes in the $\mathrm{P}, \mathrm{Fe}$, and $\mathrm{Si}$ content, as well as the systematic depletion of $\delta^{13} \mathrm{C}$, probably reflect the slow soil development at that time. The beginning of LIG optimum is connected with a rapid increase in the stalagmite growth rate, which suggests increase of dripping rate. It is supported by change in calcite fabric from columnar compact to heavy porous columnar open. The data from Western Mediterranean sites and other isotopic records suggests that it was wetter period. Thus increased dripping rate could be connected with higher rainfalls at that time. Elevated $\delta^{18} \mathrm{O}$ values and low $\delta^{13} \mathrm{C}$ corresponds with other data from the region and suggest warm and wet period with developed vegetation cover. Since then, the $\delta^{18} \mathrm{O}$ trend of the ocz- 6 record has become similar to trends of other European records. During the LIG optimum, the difference between $\delta^{18} \mathrm{O}$ records from different European regions was the lowest. This suggests a stronger influence of Atlantic circulation at that time and delivering more moisture of Atlantic origin to Eastern part of continent. The high variability of proxies such as $\delta^{18} \mathrm{O}, \delta^{13} \mathrm{C}, \mathrm{Mg}$, $\mathrm{Sr}, \mathrm{Fe}$ and $\mathrm{P}$ during the interglacial optimum exhibits its instability which is in accordance with data from Western Europe. The carbon isotopic record of the ocz-6 stalagmite reflects changes in vegetation and is similar to that observed in Alpine records during most of the LIG. The correlations observed between $\delta^{13} \mathrm{C}$ and $\mathrm{Fe}, \mathrm{P}, \mathrm{Si}$ content at the beginning and end of the LIG reflect the soil development process. A strong isotopic shift at the end of the ocz-6 record may suggest dry conditions that finally stopped the ocz-6 precipitation at the end of the LIG. The increasing difference between ocz- 6 record and the other record during the interglacial demise time suggest that climatic conditions become more dependent from regional settings at that time.

\section{ACKNOWLEDGMENTS}

This study was supported by a grant from the Polish Ministry of Science No-20 15/19/D/ST10/00571 and Czech-Polish bilateral project "MOBILITY PAN-17-22".

The U-series dating and geochemical analyses were supported by the Plan of Institutional financing of the Institute of Geology, The Czech Academy of Sciences No RVO 67985831.

\section{SUPPLEMENTARY MATERIAL}

Supplementary material, containing additional Figures S1 and S2, is available online at https://doi.org/10.1515/geochr-2015-0107.

\section{REFERENCES}

Bar-Matthews M, Ayalon A, Gilmour M, Matthews A and Hawkesworth C, 2003. Sea-land oxygen isotopic relationships from planktonic foraminifera and speleothems in the Eastern Mediterranean region and their implication for paleorainfall during interglacial intervals. Geochimica et Cosmochimica Acta 67: 3181-3199, DOI 10.1016/S0016-7037(02)01031-1.

Boch R, Cheng H, Spotl C, Edwards RL, Wang X and Hauselmann P, 2011. NALPS: a precisely dated European climate record 120-60 ka. Climate of the Past 7: 1247-1259, DOI 10.5194/cp-7-12472011.

Chappellaz J, Brook E, Blunier T and Malaize B, 1997. CH4 and 8180 of $\mathrm{O} 2$ records from Antarctic and Greenland ice: A clue for stratigraphic disturbance in the bottom part of the Greenland Ice Core Project and the Greenland Ice Sheet Project 2 ice cores. Journal of Geophysical Research 102: 26547-26557, DOI 10.1029/97JC00164. 
Cheng H, Edwards RL, Broecker WS, Denton GH, Kong X, Wang Y, Zhang R and Wang X, 2009. Ice age terminations. Science 326: 248-252, DOI 10.1126/science.1177840.

Cheng H, Edwards RL, Shen CC, Polyak VJ, Asmerom Y, Woodhead J, Hellstrom J, Wang Y, Kong X, Spotl C, Wang X and Alexander EC, 2013. Improvements in 230Th dating, 230Th and 234U halflife values, and UeTh isotopic measurements by multi-collector inductively coupled plasma mass spectrometry. Earth and Planetary Science Letters 371-372: 82-91, DOI 10.1016/j.eps1.2013.04.006.

Cleveland WS, 1979. Robust locally weighted regression and smoothing scatterplots. Journal of the American Statistical Association 74(368): 829-836, DOI 10.2307/2286407.

Couchoud I, Genty D, Hoffmann DL, Drysdale R and Blamart D, 2009. Millennial scale climate variability during the Last Interglacial recorded in a speleothem from South-western France. Quaternary Science Reviews 28: 3263-3274, DOI 10.1016/j.quascirev.2009.08.014.

Dansgaard W, 1964. Stable isotopes in precipitation. Tellus 16: 438468, DOI 10.1111/j.2153-3490.1964.tb00181.x.

Darling WG, 2004. Hydrological factors in the interpretation of stable isotopic proxy data present and past: a European Perspective. Quaternary Science Reviews 23: 743-770, DOI 10.1016/j.quascirev.2003.06.016.

Davis BAS and Brewer S, 2008. Orbital forcing and role of the latitudinal insolation/temperature gradient. Climate Dynamics 32: 143165, DOI 10.1007/s00382-008-0480-9.

Demeny A, Kern Z, Czuppon G, Nemeth A, Leel-Ossy S, Siklosy Z, Lin K, Hsun-Ming Hu, Chuan-Chou Shen, Vennemann TW and Haszpra L, 2017. Stable isotope compositions of speleothems from the last interglaciale Spatial patterns of climate fluctuations in Europe. Quaternary Science Reviews 161: 68-80, DOI 10.1016/j.quascirev.2017.02.012.

Dorale JA, Edwards RL, Ito E and Gonzalez LA, 1998. Climate and vegetation history of the midcontinent from 75 to $25 \mathrm{ka}$ : a speleothem record from Crevice Cave, Missouri, USA. Science 282: 1871-1874, DOI 10.1126/science.282.5395.1871.

Dorale JA and Liu Z, 2009. Limitations of Hendy Test criteria in judging the paleoclimatic suitability of speleothems and the need for replication. Journal of cave and karst studies 71(1): 73-80, DOI 10.1.1.551.9215.

Dragusin V, Balan S, Blamart D, Forray FL, Marin C, Mirea IC, Viorica N, Persoiu A, Tirla ML, Tudorache A and Vlaicu M, 2017. Transfer of environmental signals from surface to the underground at Ascunsa Cave, Romania. Hydrology and Earth System Sciences 21: 5357-5373, DOI 10.5194/hess-2016-625.

Drysdale RN, Hellstrom JC, Zanchetta G, Fallick AE, Sanchez-Goni MF, Couchoud I, McDonald J, Maas R, Lohmann G and Isola I, 2009. Evidence for obliquity forcing of glacial termination II. Science 325: 1527-1531, DOI 10.1126/science.1170371.

Drysdale RN, Zanchetta G, Hellstrom JC, Fallick AE, McDonald J and Cartwright I, 2007. Stalagmite evidence for the precise timing of North Atlantic cold events during the early last glacial. Geology 35: 77-80, DOI 10.1130/G23161A.1.

Drysdale RN, Zanchetta G, Hellstrom JC, Fallick AE and Zhao J, 2005. Stalagmite evidence for the onset of the Last Interglacial in southern Europe at $129 \pm 1$ ka. Geophysical Research Letters 32: L24708, DOI 10.1029/2005GL024658.

Dutton A and Lambeck K, 2012. Ice volume and sea level during the last interglacial. Science 337: $216-219$, DOI 10.1126/science.1205749.

Eggins MS, Woodhead DJ, Kinsley JPL, Mortimer EG, Sylvester P, McCulloch TM, Hergt JM and Handler RM, 1997. A simple method for the precise determination of $\geq 40$ trace elements in geological samples by ICPMS using enriched isotope internal standardization. Chemical Geology 134(4): 311-326, DOI 10.1016/S00092541(96)00100-3.

Evlogiev J, 2000. The Quaternary in Northeast Bulgaria. Review of the Bulgarian Geological Society 61: 1-3: 3-25. (In Bulgarian, Abstract in English).
Evlogiev JP, Karachorov M and Todorov DH, 1997. Study of the genesis of fractures in the Orlova Chuka cave, Rousse region. Geology and Hydrogeology 24: 33-39 (In Bulgarian, Abstract in English)

Fairchild IJ and Baker A, 2012. Speleothem Science: From Process to Past Environments. Wiley-Blackwell 432 ISBN:9781405196208

Frisia S, 2015. Microstratigraphic logging of calcite fabrics in speleothems as tool for palaeoclimate studies. International Journal of Speleology 44: 1-16, DOI 10.5038/1827-806X.44.1.1.

Frisia S, Borsato A, Preto N and McDermott F, 2003. Late Holocene annual growth in three Alpine stalagmites records the influence of solar activity and the North Atlantic Oscillation on winter climate. Earth and Planetary Science Letters 216(3): 411-424, DOI 10.1016/S0012-821X(03)00515-6.

Gascoyne M, 1992. Palaeoclimate determination from cave calcite deposits. Quaternary Science Reviews 11: 609-632, DOI 10.1016/0277-3791(92)90074-I.

Geilert S, Vroon PZ, Roerdink DL, van Cappellen P and van Bergen, MJ, 2014. Silicon isotope fractionation during abiotic silica precipitation at low temperatures: Inferences from flow-through experiments, Geochimica et Cosmochimica Acta 142: 95-114, DOI 10.1016/j.gca.2014.07.003.

Genty D, Verheyden S and Wainer K, 2013. Speleothem records over the last interglacial. PAGES News 21: 24-25, DOI 10.22498/pages.21.1.24

Govin A, Capron E, Tzedakis PC, Verheyden S, Ghaleb B, HillaireMarcel C, St-Onge G, StonerJS, Bassinot F, Bazin L, Blunier T, Combourieu-Nebout N, Ouahabi AE, Genty D, Gersonde R, Jimenez-Amat P, Landais A, Martrat B, Masson-Delmotte V, Parrenin F, Seidenkrantz MS, Veres D, Waelbroeck C and Zahn R, 2015. Sequence of events from the onset to the demise of the Last Interglacial: Evaluating strengths and limitations of chronologies used in climatic archives. Quaternary Science Reviews 129: 1-36, DOI 10.1016/j.quascirev.2015.09.018

Hellstrom J, 2006. U-Th dating of speleothems with high initial 230Th using stratigraphical constraint. Quaternary Geochronology 1(4): 289-295, DOI 10.1016/j.quageo.2007.01.004.

Hendy CH, 1971. The isotopic geochemistry of speleothems - I. The calculation of the effects of different modes of formation on the isotopic composition of speleothems and their applicability as palaeoclimatic indicators. Geochimica et Cosmochimica Acta 35(8): 801-824, DOI 10.1016/0016-7037(71)90127-X.

Hendy $\mathrm{CH}$ and Wilson TA, 1968. Palaeoclimatic Data from Speleothems. Nature 219: 48-51, DOI 10.1038/219048a0.

Hercman H and Pawlak J, 2012. MOD-AGE: An age-depth model construction algorithm. Quaternary Geochronology 12: 1-10, DOI 10.1016/j.quageo.2012.05.003.

Holden EN, 1990. Total half-lives for selected nuclides. Pure and Applied Chemistry 62(5): 941-958, DOI 10.1351/pac199062050941.

Holzkamper S, Mangini A, Spotl C and Mudelsee M, 2004. Timing and progression of the last Interglacial derived from a high Alpine stalagmite. Geophysical Research Letters 31: L07201, DOI 10.1029/2003GL019112.

Jaffey AH, Flynn KF, Glendenin LE, Bentley WC and Essling AM, 1971. Precision measurements of half-lives and specific activities of 235U and 238U. Physical Reviews C4: 1889-1906, DOI 10.1103/PhysRevC.4.1889.

Kandiano ES, Bauch HA and Fahl K, 2014. Last interglacial surface water structure in the western Mediterranean (Balearic) Sea: climatic variability and link between low and high latitudes. Global and Planetary Change 123: 67-76, DOI 10.1016/j.gloplacha.2014.10.004.

Lachniet MS, 2006. Climatic and environmental controls on speleothem oxygen-isotope values. Quaternary Science Reviews 28: 412-432, DOI 10.1016/j.quascirev.2008.10.021.

Landais A, Dreyfus G, Capron E, Jouzel J, Masson-Delmotte V, Roche DM, Prie, F, Caillon N, Chappellaz J, Leuenberger M, Lourantou A, Parrenin F, Raynaud D and Teste G, 2013. Two-phase change in $\mathrm{CO} 2$, Antarctic temperature and global climate during Termination II. Nature Geoscience 6: 1062-1065, DOI 10.1038/ngeo1985. 
Lauritzen SE and Onac BP, 1999. Isotopic stratigraphy of a last interglacial stalagmite from the Northwestern Romania: Correlation with the Deep-sea record and Northern-Latitude speleothem. Journal of Cave and Karst Studies 61(1): 22-30.

Linge, H, Lauritzen SE and Lundberg J, 2001. Stable isotope stratigraphy of a late last interglacial speleothem from Rana, northern Norway. Quaternary Research 56: 155-164, DOI 10.1006/qres.2001.2254.

Malcheva K, Gocheva A and Chervenkov H, 2015. Winter Circulation Conditions over the Bulgaria. 15th International Multidisciplinary Scientific GeoConference SGEM 2015, Book4: 1129-1136, DOI 10.5593/SGEM2015/B41/S19.145.

Mangini A, Spotl C and Verdes P, 2005. Reconstruction of temperature in the Central Alps during the past $2000 \mathrm{yr}$ from a $\delta^{18} \mathrm{O}$ stalagmite record. Earth and Planetary Science Letters 235: 741-751, DOI 10.1016/j.epsl.2005.05.010.

Martinson DG, Pisias NG, Hays JD, Imbrie J, Moore Jr, TC and Shackleton NJ, 1987. Age dating and the orbital theory of the ice ages: development of a high-resolution 0 to 300,000-year chronostratigraphy. Quaternary Research 27: 1-29, DOI 10.1016/00335894(87)90046-9.

Masson-Delmotte V, Schulz M, Abe-Ouchi A, Beer J, Ganopolski A, Gonzalez Rouco JF, Jansen E, Lambeck K, Luterbacher J, Naish T, Osborn T, Otto-Bliesner B, Quinn T, Ramesh R, Rojas M, Shao X, Timmermann A, 2013. Information from paleoclimate archives. In: Stocker TF, Qin D, Plattner GK, Tignor M, Allen SK, Boschung J, Nauels A, Xia Y, Bex V, Midgley PM, Eds, Climate Change 2013: the Physical Science Basis. Contribution of Working Group I to the Fifth Assessment Report of the Intergovernmental Panel on Climate Change. Cambridge University Press, Cambridge, United Kingdom and New York, NY, USA: 383-464 (Chapter 5).

Masson-Delmotte V, Stenni B, Pol K, Braconnot P, Cattani O, Falourd S, Kageyama M, Jouzel J, Landais A, Minster B, Barnola JM, Chappellaz J, Krinner G, Johnsen S, Rothlisberger R, Hansen J, Mikolajewicz U, Otto-Bliesner B, 2010. EPICA Dome C record of glacial and interglacial intensities. Quaternary Science Reviews 29: 113-128, DOI 10.1016/j.quascirev.2009.09.030.

Meyer MC, Spotl C, Mangini A, 2008. The demise of the Last Interglacial recorded in isotopically dated speleothems from the Alps. Quaternary Science Reviews 27: 476-496, DOI 10.1016/j.quascirev.2007.11.005.

Milner AM, MüllerUC., Roucoux KH, Collier RE, Pross J, Kalaitzidis S, Christanis K and Tzedakis PC, 2013. Environmental variability during the Last Interglacial: a new high-resolutin pollen record from Tenaghi Philippon, Greece. Journal of Quaternary Science 28: 113-117. DOI 10.1002/jqs.2617.

Moseley GE, Spotl C, Cheng H, Boch R, Min A and Edwards RL, 2015. Termination-II interstadial/stadial climate change recorded in two stalagmites from the north European Alps. Quaternary Science Reviews 127: 229-239, DOI 10.1016/j.quascirev.2015.07.012.

Munoz-García MB, Martín-Chivelet J, Rossi C, Ford DC and Schwarcz HP, 2007. Chronology of Termination II and the Last Interglacial Period in North Spain based on stable isotope records of stalagmites from Cueva del Cobre (Palencia). Journal of Iberian Geology 33: $17-30$.

Müller UC and Kukla GJ, 2004. North Atlantic Current and European environments during the declining stage of the last interglacial. Geology 32: 1009-1012, DOI 10.1130/G20901.1.

Nehme C, Verheyden S, Noble SR, Farrant AR, Sahy D, Hellstrom J, Delannoy JJ, Claeys P, 2015. Reconstruction of MIS 5 climate in the central Levant using a stalagmite from Kanaan Cave. Lebanon. Climate of the Past 11: 1785-1799, DOI 10.5194/cp-11-17852015.
Nojarov P, 2018. Factors affecting air temperature in Bulgaria. Theoretical and Applied Climatology 1-16, DOI 10.1007/s00704-0182622-2.

Oppo DW, McManus JF and Cullen J, 2006. Evolution and demise of the Last Interglacial warmth in the subpolar North Atlantic. Quaternary Science Reviews 25: 3268-3277, DOI 10.1016/j.quascirev.2006.07.006.

Otvos EG, 2015. The Last Interglacial Stage: Definitions and marine highstand, North America and Eurasia. Quaternary International 383: 158-173, DOI 10.1016/j.quaint.2014.05.010.

Pedersen RA, Langen PL and Vinther BM, 2017. The last interglacial climate: comparing direct and indirect impacts of insolation changes Climate dynamic 48: 3391-3407, DOI 10.1007/s00382016-3274-5.

Regattieri E, Zanchetta G, Drysdale RN, Isola I, Hellstrom JC and Roncioni A, 2014. A continuous stable isotope record from the penultimate glacial maximum to the Last Interglacial (159-121 ka) from Tana Che Urla Cave (Apuan Alps, central Italy). Quaternary Research 82: 450-461, DOI 10.1016/j.yqres.2014.05.005.

Różański K, Araguas-Araguas L and Gonfiantini R, 1993. Isotopic Patterns in Modern Global Precipitation. Climate Change in Continental Isotopic Records 78: 1-36, DOI 10.1029/GM078.

Shumilovskikh L, Arz H, Wegwerth A, Fleitmann D, Marret F, Nowaczyk N, Tarasov P and Behling H, 2013. Vegetation and environmental changes in Northern Anatolia between 134 and $119 \mathrm{ka}$ recorded in Black Sea Sediments. Quaternary Research 80(3): 349-360, DOI 10.1016/j.yqres.2013.07.005.

Shackleton NJ, 1969. The Last Interglacial in the marine and terrestrial records. Proceedings of the Royal Society B 174: 135-154, DOI 10.1098/rspb.1969.0085

Sirocko F, Seelos K, Schaber K, Rein B, Dreher F, Diehl M, Lehne R, Jager K, Krbetschek M and Degering D, 2005. A Late Eemian Aridity Pulse in central Europe during the last glacial inception. Nature 436: 833-836, DOI 10.1038/nature03905.

Stone EJ, Capron E, Lunt DJ, Payne AJ, Singarayer JS, Valdes PJ and Wolff EW, 2016. Impact of meltwater on high-latitude early Last Interglacial climate. Climate of the Past 12: 1919-1932, DOI 10.5194/cp-12-1919-2016.

Treble P, Shelley JMG and Chappell J, 2003. Comparison of high resolution sub-annual records of trace elements in a modern (1911-1992) speleothem with instrumental climate data from southwest Australia. Earth and Planetary Science Letters 216: 141-153, DOI 10.1016/S0012-821X(03)00504-1.

Turgeon S and Lundberg J, 2001. Chronology of discontinuities and petrology of speleothems as paleoclimatic indicators of the Klamath Moutains, Southwest Oregon, USA. Carbonates and Evaporites 16(2): 153-167, DOI 10.1007/BF03175833.

Tzedakis PC, 1994. Vegetation change through glacial—interglacial cycles: a long pollen sequence perspective. Philosophical Transactions of Royal Society Biological Sciences 345(1314), DOI: 10.1098/rstb.1994.0118.

Vansteenberge S, Verheyden S, Cheng H, Edwards RL, Keppens E and Claeys P, 2016. Paleoclimate in continental northwestern Europe during the Eemian and early Weichselian (125-97ka): insights from a Belgian speleothem. Climate of the Past 12: 1445-1458, DOI 10.5194/cp-12-1445-2016.

Williams PW, Marshall A, Ford DC and Jenkinson AV, 1999. Palaeoclimatic interpretation of stable isotope data from Holocene speleothems of the Waitomo district, North Island, New Zealand. The Holocene 9: 649-657, DOI 10.1191/095968399673119429.

Zumbühl A, 2010. History of the Black Sea recorded in stalagmites from Northern Turkey. Master's Thesis Faculty of Science University of Bern, 1-115. 